\title{
Environomic optimal configurations of geothermal energy conversion systems: application to the future construction of Enhanced Geothermal Systems in Switzerland
}

\author{
Laboratory for Industrial Energy Systems, Ecole Polytechnique Fédérale de Lausanne \\ $\mathrm{CH}$ - 1015 Lausanne, Switzerland \\ Léda Gerber, François Maréchal
}

Accepted by Energy on 25.06.2012

\begin{abstract}
The development of Enhanced Geothermal Systems (EGS) for the cogeneration of electricity and district heating is expected to be important in the future. The criteria to be accounted for in the energy conversion system design are the economic profitability, the thermodynamic efficiency in the usage of the resource, and the generated life-cycle environmental impacts, which are as well a key point for the public acceptance of geothermal energy. This paper presents a systematic methodology for the optimal design and configuration of geothermal systems considering environomic criteria. Process design and process integration techniques are used in combination with Life Cycle Assessment (LCA) and multiobjective optimization techniques, using a multi-period strategy to account for the seasonal variations in the district heating demand. It is illustrated by an application to the future EGS construction for cogeneration in the context of Switzerland. Different conversion cycles are considered: single and double flash systems, organic Rankine cycles (ORC), and Kalina cycles. The optimal configuration is determined at each construction depth for the EGS from 3000 down to $10000 \mathrm{~m}$ and at each district heating network installed capacity from 0 to $60 \mathrm{MW}_{t h}$. Results show that in the shallowest range of depths $(3500-6000 \mathrm{~m})$, the optimal configurations for all considered performance indicators are EGS between 5500 and $6000 \mathrm{~m}$ with a Kalina cycle for cogeneration, and a district heating network with an installed capacity between 20 and $35 \mathrm{MW}_{t h}$. In the deepest range $(7500-9500 \mathrm{~m})$, when compared with the single electricity production, the cogeneration of district heating is less favorable from an economic and exergetic perspective $(11 \%$ and $17 \%$ of relative penalty, respectively, for a district heating network with an installed capacity of $60 \mathrm{MW}_{t h}$ ) but more favorable in terms of environmental performance (37\% of relative improvement for avoided $\mathrm{CO} 2$ emissions).
\end{abstract}

\section{Nomenclature}

$\dot{E}_{p}^{-}$net electrical power produced by system at the operating conditions of period $p$, in $\mathrm{MW}_{e}$

$\dot{E}_{t}^{-}$electrical power produced by the turbines of the cycle, in $\mathrm{MW}_{e}$

$\dot{f} u_{p}$ quantity of functional unit involved during period $p$

$\dot{I}_{O}$ impact due to the operation phase

$\dot{m}_{\text {ext }}$ extracted mass flow rate from EGS, in $\mathrm{kg} / \mathrm{s}$

$\dot{m}_{f}$ mass flow rate of geothermal steam passing through the flash system turbine, in $\mathrm{kg} / \mathrm{s}$

$\dot{m}_{i n j}$ injected mass flow rate in EGS, in $\mathrm{kg} / \mathrm{s}$ 
$\dot{m}_{i}$ mass flow rate of emission of substance $i$ from flash system condensers, in kg- $i / \mathrm{kg}$-geofluid $\dot{m}_{\text {mkup }}$ mass flow rate of make-up water for EGS, in $\mathrm{kg} /$

$\dot{m}_{\text {scal }}$ quantity of scaling and residues from EGS to be disposed, in $\mathrm{kg} / \mathrm{s}$

$\dot{Q}_{\text {max }}^{-}$district heating network installed capacity, in $\mathrm{MW}_{t h}$

$\dot{Q}_{p}^{-}$district heating requirement during period $p$, in $\mathrm{MW}_{t h}$

$\eta$ exergy efficiency of the conversion system, in \%

$c_{e}^{-}$selling price of electricity, in $\mathrm{USD} / \mathrm{kWh}_{e}$

$C_{i n v, a n}$ annualized total investment costs, in USD/yr

$C_{i n v, D H}$ investment costs associated with the district heating network, in USD

$C_{i n v, E G S}$ investment costs associated with the EGS construction

$C_{i n v, t o t}$ total investment costs of EGS, conversion system and district heating network, in USD

$C_{i n v, w}$ investment costs associated with equipment $w$, in USD

$c_{o, E G S}$ specific operating costs of EGS, in USD $/ \mathrm{h}$

$c_{o, t}$ specific operating costs of conversion technology $t$, in USD $/ \mathrm{h}$

$c_{q}^{-}$selling price of district heating, in $\mathrm{USD} / \mathrm{kWh}_{t h}$

$e_{i}$ emission factor of substance $i$ from the flash system condensers, in $\mathrm{kg}-i / \mathrm{kg}$-geofluid

$e_{C O 2, N G C C}$ specific $\mathrm{CO} 2$ emissions of electricity production from NGCC, in $\mathrm{kg} \mathrm{CO} 2$-eq $/ \mathrm{kWh}_{e}$

$e_{C O 2, N G C C}$ specific $\mathrm{CO} 2$ emissions of heating production from natural gas boiler, in $\mathrm{kg} \mathrm{CO} 2-$ $\mathrm{eq} / \mathrm{kWh}_{t} h$

$E_{C O 2, a v}$ yearly avoided life-cycle $\mathrm{CO} 2$-equivalent emissions, in $\mathrm{kg} \mathrm{CO} 2$-eq/yr

$I_{C}$ impact due to the construction phase

$I_{E}$ impact due to the end-of-life phase

$I_{F U}$ final impacts per functional unit

$l_{\text {wat }}$ water losses in EGS, in \%

$L_{w f}$ losses and required make-up of working fluid in binary cycles, in $\mathrm{kg} / \mathrm{yr}$

$l_{w f}$ yearly losses of working fluid in binary cycles, in $\%$

$M_{k}$ required quantity of auxiliary material $k$

$M_{w f}$ initial quantity of working fluid in binary cycles, in $\mathrm{kg}$

$n_{w}$ number of wells

$n_{e c}$ number of LCI elements associated with construction phase

$n_{e e}$ number of LCI elements associated with end-of-life phase

$n_{e o}$ number of LCI elements associated with operation phase 
$R_{a n}$ annual revenue, in USD/yr

$s$ success factor in achieving the EGS sub-surface plant construction, in $\%$

$T_{\text {out }}$ outlet temperature at which hot source is cooled, in ${ }^{\circ} \mathrm{K}$

$t_{p}$ duration of period $p$, in $\mathrm{h}$

$T_{a}$ ambient temperature, in ${ }^{\circ} \mathrm{K}$

$T_{\text {in }}$ inlet temperature of the hot source, in ${ }^{\circ} \mathrm{K}$

$T_{l m}$ logarithmic mean temperature, in ${ }^{\circ} \mathrm{K}$

$t_{p b}$ payback period, in yr

$t_{y r}$ expected lifetime of the EGS reservoir, in yr

$v_{k}$ reference quantity of auxiliary material $k$

$v_{\text {scal }}$ quantity of scaling and residues per mass unit of geothermal water, in $\mathrm{kg}$-residues $/ \mathrm{kg}$ geofluid

$x_{d}$ decision variables of the non-linear MOO problem

$y_{w f}$ thermodynamic properties of working fluid in binary cycles

$z$ EGS construction depth, in $\mathrm{m}$

CHP Combined Heat and Power

EGS Enhanced Geothermal Systems

IPCC Intergovernmental Panel on Climate Change

Kalina Kalina cycle based on the KCS-11 design

LCA Life Cycle Assessment

LCI Life Cycle Inventory

LCIA Life Cycle Impact Assessment

MILP Mixed Integer Linear Programming

MINLP Mixed Integer Non-Linear Programming

MOO Multi-Objective Optimization

NGCC Natural Gas Combined Cycle

ORC Organic Rankine Cycle

ORC-2 ORC with two evaporation levels

ORC-d ORC with an intermediate draw-off at the turbine

ORC-s supercritical ORC 


\section{Introduction}

In the perspective of increasing the share of renewable energy to mitigate global warming issues and to respond to fossil resources depletion, the use of geothermal energy has gained interest. Major applications of geothermal energy include electricity production (67246 $\mathrm{GWh}_{e} / \mathrm{yr}$ in 2010$)$ and direct use for heating (117740 $\mathrm{GWh}_{t h} / \mathrm{yr}$ in 2010) Lund and Bertani (2010). As stated by the International Energy Agency in its roadmap for geothermal energy IEA (2011), by 2050 the geothermal power production should be increased to $1400 \mathrm{TWh}_{e} / \mathrm{yr}$, and the direct heating use to $1600 \mathrm{TWh}_{t h} / \mathrm{yr}$. These objectives have to be reached by developing both conventional resources like hydrothermal aquifers and emerging ones like Enhanced Geothermal Systems (EGS). Hence, geothermal Combined Heat and Power (CHP) production from EGS is expected to know an important development in the future. Moreover, several countries including Switzerland have recently taken the political decision to abandon progressively nuclear power, which supposes to develop alternatives energy sources for power production.

However, the economic competitiveness of geothermal energy is still a critical point IEA (2011), and several methodologies have been developed to increase its cost-effectiveness by an optimal system design. Important aspects to be accounted for are the geothermal resources characteristics Franco and Vaccaro (2012), the design of the conversion cycle, which has to be optimized to maximize its efficiency Franco and Vaccaro (2012); Franco and Villani (2009); Hettiarachchi et al. (2007), the choice of the working fluid for binary cycles Saleh et al. (2007); Heberle and Brüggemann (2010); Guo et al. (2011a,b), and the district heating parameters for CHP applications Guo et al. (2011a,b). The thermodynamic performance is as well critical to ensure an efficient use of the resource, and it can be assessed using the exergy efficiency DiPippo (2004); Kanoglu and Dincer (2009); Coskun et al. (2011); Ganjehsarabi et al. (2011). Accounting for the two criteria, the thermo-economic approach has been applied to the analysis of geothermal systems in several studies Ozgener et al. (2007); Shengjun et al. (2011); Astolfi et al. (2011); Chamorro et al. (2012). Recently, Lazzaretto et al. Lazzaretto et al. (2011) have demonstrated its validity to design geothermal power plants. In a previous work Gerber and Maréchal (2012), we have developed a methodology integrating all the above aspects in a multi-objective optimization framework, using a multi-period approach and process integration techniques to identify the thermo-economic optimal configurations of geothermal systems in areas where the geothermal resource potential has been assessed. 
A third aspect, relevant for the public acceptance, is the environmental dimension. Indeed,Evans et al. Evans et al. (2009) demonstrated that geothermal energy may have higher impacts on the environment when compared with other renewable energy sources such as hydro, wind and solar, though their study was mostly based on existing hydrothermal systems for power generation and not on EGS. Thus, this aspect should be as well integrated in the design of geothermal energy conversion systems. Regarding the evaluation of renewable energy systems, Life Cycle Assessment (LCA) is the most appropriate methodology, since it accounts for a wide range of environmental impacts and considers the overall life cycle in a quantitative way ISO (2006a,b). Though many previous studies discuss the environmental impacts of geothermal systems DiPippo (1991); Mock et al. (1997); Rybach (2003); Kristmannsdottir and Armannsson (2003), very few use a quantitative life cycle perspective. Among them, Saner et al. Saner et al. (2010) performed a LCA for shallow geothermal systems, and Santoyo-Castelazo et al. SantoyoCastelazo et al. (2011) for electricity generation from hydrothermal systems in Mexico. To our knowledge, Frick et al. Frick et al. (2010) are the only authors who performed an environmental analysis by LCA specifically for power generation from EGS, considering the use of binary cycles. They demonstrate the relevance of using a life cycle approach for the environmental evaluation of EGS and found that the efficiency of the conversion cycle is a critical parameter. However, they use a scenario approach based on average technologies, and do not consider systematically the thermo-economic optimal configurations of geothermal systems in the impact assessment. In a previous study Gerber et al. (2011), we have developed such a methodology for the integration of LCA in the conceptual design of renewable energy conversion systems. It was demonstrated that accounting for the environmental impacts in the process design procedure is critical for an accurate impact assessment of an emerging technology and for identifying the potential for the mitigation of various environmental impacts (e.g. greenhouse gases, cumulative energy demand, acidification, ...) at an early development stage. The method was however not yet applied to geothermal conversion systems.

Therefore, this paper aims at combining the thermo-economic multi-objective optimization approach for the identification of optimal configurations of geothermal systems presented in Gerber and Maréchal (2012) with the methodology for the integration of LCA in the conceptual design of renewable energy systems presented in Gerber et al. (2011). The resulting method is illustrated by an application case study, aiming at calculating and analyzing the environmental impacts of the thermo-economic optimal configurations for a mature EGS technology in the 
economic and geological context of Switzerland, considering CHP.

\section{Methodology}

The geothermal system design aims at defining, for a given geographical location, the geothermal resource depth, the conversion system configuration in terms of equipment sizes and operating conditions, as well as the operation strategy to supply the energy services in the area (i.e. electricity and district heating). The design problem is by essence multi-period, accounting for the seasonal variations of the district heating demand. Due to the geological uncertainties, the present methodology is applicable only to support the decision-making for the future development of geothermal energy in a given area where the geology is known and the demand in energy services characterized. The proposed method does not consider seasonal heat storage. It is used for preliminary design, leading to promising configurations for which the detailed system engineering, like in Lazzaretto et al. Lazzaretto et al. (2011), is still to be done.

\subsection{Computational framework}

The general computational framework (Figure 1) aims at structuring and organizing the information in order to represent the possible interactions between the different components to be considered in the system design, and has already been described in details in Gerber and Maréchal (2012).

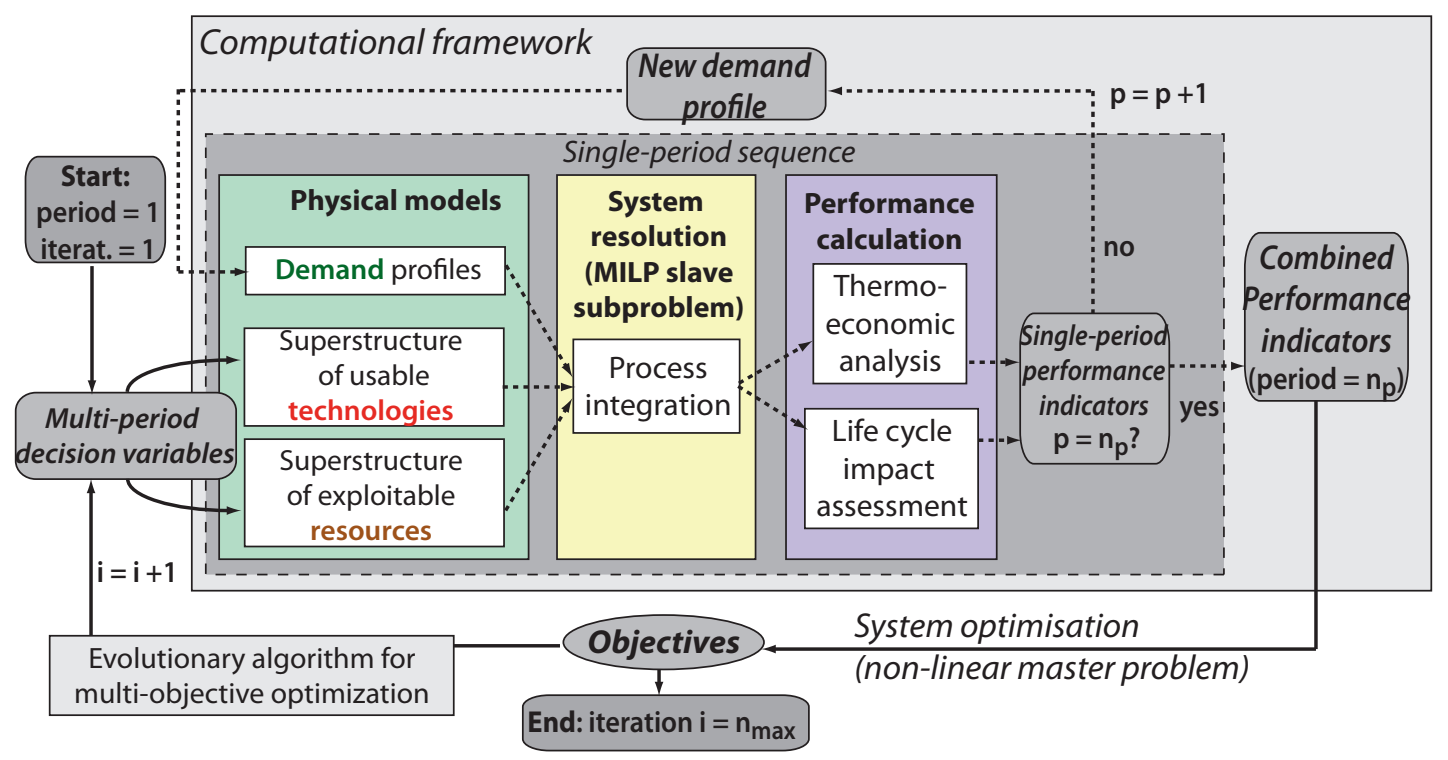

Figure 1: Computational framework for geothermal system design and simulation, adapted from Gerber and Maréchal (2012) 
A superstructure including the optional technological solutions and the potential resources is built and the thermo-economic models of these components are developed. First the three different sub-systems composing a geothermal system are simulated separately. These include:

1. the geothermal resources from which heat can be harvested

2. the conversion technologies

3. the geo-localized demand profiles in energy services

Each model of the resource and of the technologies are included in the superstructure, and the seasonal demand in energy services is simulated for a given set of operating conditions $\left(\operatorname{period}=1 \ldots n_{p}\right)$.

These sub-systems are then integrated using process integration techniques Linnhoff et al. (1982); Maréchal and Kalitventzeff (1998) to build the complete energy conversion system. The process integration model is solved as a Mixed Integer Linear Programming (MILP) sub-problem, which decision variables are the utilization rates of the technologies in the superstructure during the different periods. This step allows to calculate the system performances without having to design a priori a heat exchanger network, which will be realized once the optimal conditions are identified. Finally, the results of the simulation and of the process integration are used for equipment sizing and thereby to estimate the cost of the equipments such as turbines, pumps, heat exchangers or flash drums. Non-linear power correlations from Turton et al. Turton et al. (1998) and Ulrich Ulrich (1996) are used for calculating the grass root cost associated with each equipment, which is in agreement with the cost calculation strategies adopted in previous studies Shengjun et al. (2011); Astolfi et al. (2011); Lazzaretto et al. (2011). The validity ranges for the size of the geothermal equipments have been based on the data available in DiPippo DiPippo (2008) for the different conversion technologies. The thermo-economic performances and Life Cycle Impact Assessment (LCIA) of the integrated system are calculated, based on the process operating conditions and on the system design. The yearly operating performances are obtained by maximizing the revenues of the combined heat and power production in each of the periods. Combining the operating performances with the investment allows to develop life cycle impact and economic indicators that can be used at a master level to realize a multi-objective optimization. The multi-objective Mixed Integer Non-Linear Programming (MINLP) problem is then solved using an evolutionary algorithm that repeats the calculations for $n_{\max }$ evaluations Molyneaux et al. (2010). The decision variables of the master problem relate to: 
1. the definition of the configuration extracted from the superstructure using integer variables (i.e. if a particular technology is used or not)

2. the system operating conditions (i.e. temperatures, pressures, splitting fractions) in each period

3. the depth of the geothermal resource harvesting system (i.e. well size)

4. the share between electricity and district heating produced from the available geothermal heat in the area

The thermo-economic models are briefly described in subsection 2.2. A more detailed description of the calculation methods and models can be found in Gerber and Maréchal (2012). Subsection 2.3 describes how these models were extended to incorporate life cycle inventories and the corresponding impact assessment methods.

\subsection{Thermo-economic model description}

\subsubsection{Geothermal resource}

In a given location, the exploitable geothermal resources are defined by depth, temperature and expected mass flow rates. For EGS, the model assumes a mature commercial technology with one injection well and two extraction wells. Considering that EGS projects have a planned extraction mass flow rate between 70 and $100 \mathrm{~kg} / \mathrm{s}$ Cuenot et al. (2008); Tester et al. (2006); Haring (2004), a value of $90 \mathrm{~kg} / \mathrm{s}$ was assumed. The minimal reinjection temperature is assumed to be $70^{\circ} \mathrm{C}$ and the temperature difference between the bedrock temperature and the geofluid at the extraction well to be $20^{\circ} \mathrm{C}$ Cuenot et al. (2008). The depth of the wells is considered customizable, and goes from 3000m (i.e. the upper limit of the bedrock in Switzerland) down to 10000m (i.e. the limit for the accessible resource with the current drilling technology Tester et al. (2006)). The calculated geothermal gradient for the present case study is $0.0352^{\circ} \mathrm{C} / \mathrm{m}$ from $3000 \mathrm{~m}$ Sprecher (2011). Figure 2 shows the resource temperature Sprecher (2011) and the drilling costs for one well, interpolated using a power law with the data from Tester et al. (2006) and updated with the current inflation rate, as a function of the resource depth.

\subsubsection{Conversion technologies}

The original superstructure of potential conversion technologies described in Gerber and Maréchal (2012) contains single and double-flash systems, organic Rankine cycles (ORC) with different 


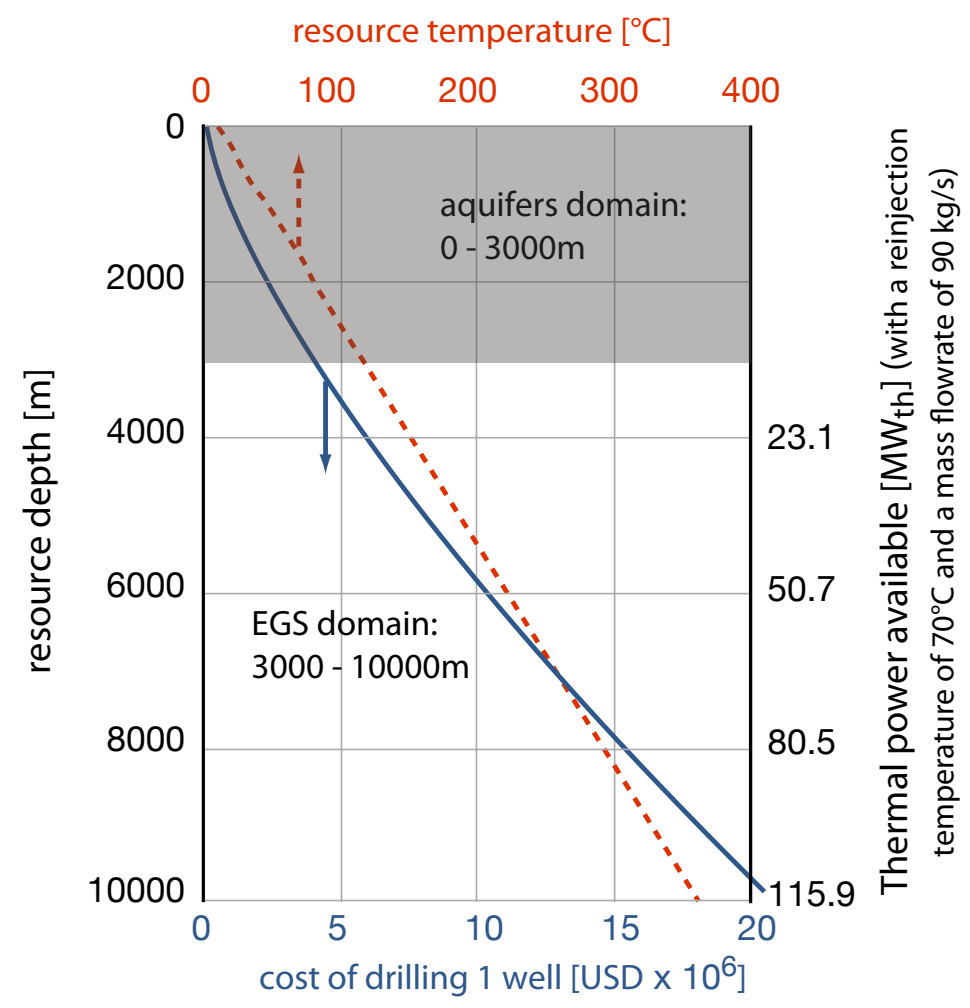

Figure 2: Temperature (calculated from Sprecher (2011)) and economic (calculated from Tester et al. (2006)) models in function of geothermal resource depth

working fluids, without or with an intermediate draw-off (ORC-d). The superstructure was extended to include a Kalina cycle based on the KCS-11 design Mlcak (2002), supercritical ORCs (ORC-s) and ORCs with two evaporation levels (ORC-2). To simulate the cycles, the flowsheeting software Belsim-Vali Belsim (2011) is used. For the ORC configurations, different organic working fluids can be used Minder et al. (2007), described in Table 1.

\begin{tabular}{|l|l|l|l|l|}
\hline Fluid & $\begin{array}{l}\text { Molecular } \\
\text { Weight } \\
{[\mathrm{kg} / \mathrm{kmol}]}\end{array}$ & $\begin{array}{l}\text { Critical } \\
\text { tempera- } \\
\left.\text { ture [ }{ }^{\circ} \mathrm{C}\right]\end{array}$ & $\begin{array}{l}\text { Critical } \\
\text { pressure } \\
{[\text { bar }]}\end{array}$ & $\begin{array}{l}\text { Boiling } \\
\text { tempera- } \\
\text { ture }\left[{ }^{\circ} \mathrm{C}\right]\end{array}$ \\
\hline n-pentane & 72.151 & 196.63 & 33.75 & 36.05 \\
cyclo-butane & 56.108 & 186.85 & 49.85 & 12.51 \\
iso-butane & 58.124 & 134.98 & 36.48 & -11.83 \\
iso-pentane & 72.151 & 187.25 & 33.34 & 27.85 \\
benzene & 78.114 & 288.95 & 49.24 & 80.15 \\
toluene & 92.141 & 318.85 & 42.15 & 110.65 \\
n-butane & 58.124 & 152.01 & 37.97 & -0.48 \\
R134a & 102.032 & 101.06 & 40.59 & -26.07 \\
\hline
\end{tabular}

Table 1: Characteristics of the different potential working fluids included in the ORCs models (taken from Belsim database) 


\subsubsection{District heating demand}

The geo-localized seasonal demand profiles in district heating considering four periods with different operating conditions have been identified for a residential area located in the Swiss Plateau following the method of Girardin et al. Girardin et al. (2010) and have been presented in Gerber and Maréchal (2012). The goal of our study is to calculate the most interesting share between the electricity production and the heat production. The nominal installed capacity of the district heating system is therefore considered as a decision variable while the temperature profiles are considered as being independent of the area covered by the district heating.

\subsection{Life Cycle Assessment model}

In the present study, the objective of the Life Cycle Assessment (LCA), integrated in the framework for geothermal system design, is to obtain LCIA indicators reflecting the influence of the energy conversion system design and of the EGS depth on the system performances. Thus, the life cycle inventory (LCI) elements have to be expressed as a function of the system configuration. The adapted LCA methodology for the conceptual design of energy systems presented in Gerber et al. (2011) is therefore applied. It follows the mandatory stages to conduct a LCA, according to the ISO-norm ISO (2006a,b): the goal and scope definition, the life cycle inventory, the impact assessment, and the interpretation.

\subsubsection{Goal and Scope definition}

The LCA aims at comparing the environmental performance of the different geothermal system configurations for a wide range of environmental impacts, considering not only their greenhouse gases mitigation potential, but as well the effects on human health, ecosystem quality and nonrenewable resources, accounting for the overall life cycle from cradle-to-grave. Therefore, the functional unit is defined as the construction, operation and dismantling of one EGS, to produce electricity and heat. The substitution of produced energy services (i.e. avoided impacts from conventional production of electricity and heating by fossil resources) has to be included, to account for the efficiency of the conversion system. An expected lifetime of 30 years is assumed for the EGS.

\subsubsection{Life Cycle Inventory}

The Life Cycle Inventory (LCI) model concerns three types of elements Gerber et al. (2011): 
1. the flows and the emissions calculated by the thermo-economic model and having an environmental significance (e.g. the water make-up for EGS during operation or the produced energy services)

2. the auxiliary materials and emissions of environmental significance not directly included in the thermo-economic models but necessary for the construction and operation of the system (e.g. the steel for the well casing or the working fluid losses in the binary cycles)

3. the process equipment, which is included in the thermo-economic model (e.g. the geothermal pumps or the turbines for electricity production)

These different elements have first to be identified, either from existing thermo-economic models, for the equipment and for the flows of the thermo-economic models, or from the literature for the auxiliary materials and emissions. The resulting LCI model for the life cycle of an EGS is presented in Figure 3.

Transportation of auxiliary materials is not displayed in the figure but is included in the LCI model. The avoided impacts from the produced energy services are calculated by substitution of the equivalent services produced from fossil natural gas sources with the currently best available technologies. For the electricity production, a natural gas combined cycle (NGCC) power plant with an electrical efficiency of $57 \%$ is assumed while a natural gas boiler with an efficiency of $95 \%$ is assumed for the heat supply. In order to account for the off-site emissions, the LCI database ecoinvent ${ }^{\circledR}$ Frischknecht et al. (2005) is used to find equivalences for each LCI element.

In the second step of the LCI, emissions are scaled using the thermo-economic model results. For the flows and emissions already included in the thermo-economic model, the value is directly taken from it. This is the case for the amounts of electricity and of district heating produced, and for the water make-up for injection, during the use phase. For process equipment, the methodology presented in Gerber et al. (2011) is used for a non-linear impact scaling. For auxiliary materials, the formulation has to be developed case-by-case.

The quantities of auxiliary materials required for the site preparation are expressed as:

$$
M_{k, s p}=\frac{v_{k}}{s}
$$

where $M_{k, s p}$ is the required quantity of the auxiliary material, $k$, for the site preparation, $v_{k}$ is its reference quantity needed per site and $s$ is the percentage of success in achieving the EGS 


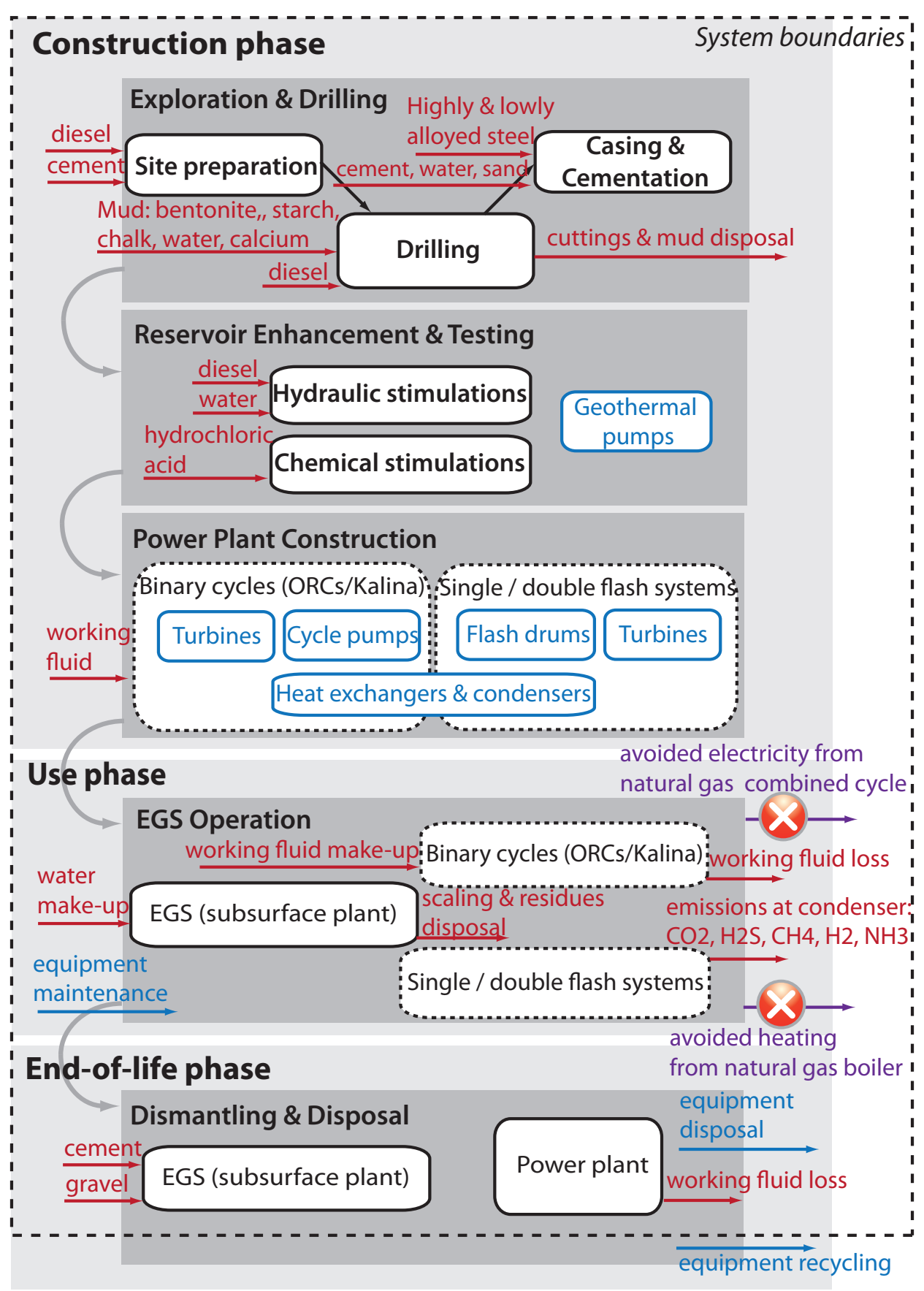

Figure 3: Major flows (red), equipment (blue), and substituted services (purple) included in the LCI of an EGS

sub-surface plant construction in a given project. For example, an $s$ of $50 \%$ means that two sites have to be explored, drilled and enhanced before an EGS can be successfully operated. For the base case, a full success is assumed. The values for the $v_{k}$ are taken from Frick et al. Frick et al. (2010). 
The quantities of auxiliary materials required for the drilling and for the casing and cementation are expressed as:

$$
M_{k, d c}=\frac{v_{k} \cdot z \cdot n_{w}}{s}
$$

where $z$ is the EGS targeted construction depth and $n_{w}$ is the number of wells that have to be drilled. The values for the $v_{k}$ are taken from Frick et al. Frick et al. (2010).

The quantities of auxiliary materials required for the reservoir enhancement are expressed as:

$$
M_{k, r e}=\frac{v_{k} \cdot n_{w}}{s}
$$

The $v_{k}$ values are taken from Frick et al. Frick et al. (2010) for the hydraulic stimulations, and from Portier et al. Portier et al. (2009) for the chemical stimulations.

For the binary power plant construction (ORCs or Kalina), the quantity of working fluid initially required was calculated from data in Frick et al. (2010) for iso-butane, and then adapted proportionally to the power output of the cycle and as a function of the thermodynamic properties of the working fluid.

The quantity of make-up water during EGS operation is expressed as:

$$
\dot{m}_{\text {mkup }}=l_{\text {wat }} \cdot \dot{m}_{i n j}
$$

where $l_{\text {wat }}$ are the water losses in the EGS, assumed to be $10 \%$ according to Minder et al. Minder et al. (2007). Thus, the reinjected mass flow rate $\dot{m}_{i n j}$ corresponds to $100 \mathrm{~kg} / \mathrm{s}$ for the case study.

The quantity of scaling and residues that have to be disposed during the EGS operation is expressed as:

$$
\dot{m}_{\text {scal }}=v_{\text {scal }} \cdot \dot{m}_{\text {ext }}
$$

where $v_{\text {scal }}$ is the quantity of scaling and residues per $\mathrm{kg}$ of geothermal water, equal to 1.5 $\mathrm{kg} / \mathrm{yr} \cdot \mathrm{m}^{3} / \mathrm{h}$ Frick et al. (2010), and $\dot{m}_{\text {ext }}$ is the extracted mass flow rate..

The yearly losses and required make-up of working fluid for binary cycles during the EGS operation are expressed as:

$$
L_{w f}=M_{w f}\left(\dot{E}_{t}^{-}\left(z, \dot{Q}_{\text {max }}^{-}, x_{d}\right), y_{w f}\right) \cdot l_{w f}
$$


where $M_{w f}$ is the initial required quantity of working fluid, $\dot{E}_{t}^{-}$is the electrical power produced by the turbines of the cycle, which is function of the resource temperature at depth $z$, of the district heating network installed capacity $\dot{Q}_{\max }^{-}$and of the design decision variables of the conversion system $x_{d} . y_{w f}$ are the thermodynamic properties of the chosen working fluid and $l_{w f}$ are the yearly losses of the working fluid, which are between 0 and $2 \%$, according to Ormat ${ }^{\circledR}$ Ormat (2010). The maximum $l_{w f}$ value of $2 \%$ is assumed in the present study.

The emissions of non-condensable gases from the condenser for flash systems during the EGS operation are expressed as:

$$
\dot{m}_{i, e m}=e_{i} \cdot \dot{m}_{f}\left(\dot{E}_{t, p}^{-}\left(z, \dot{Q}_{p}^{-}, x_{d}\right)\right)
$$

where $e_{i}$ is the emission factor of the non-condensable gas $i$, in $\mathrm{kg}$ of substance $i$ per $\mathrm{kg}$ of geothermal water, $\dot{m}_{f}$ the mass flow rate passing through the flash system turbine and the condenser, depending on the electricity produced by turbines during period $p$, function of the depth and of the district heating required during period $p \dot{Q}_{p}^{-}$. No data are currently available for emissions from flash systems using EGS. Thus, data for such emission factors from hydrothermal systems from Baldacci et al. Baldacci et al. (2002) have been used for CO2, H2S, CH4, H2 and NH3. For CO2, emissions were as well available per $\mathrm{MWh}_{e}$ of produced electricity from other sources DiPippo (2008); Brown and Ulgiati (2002); Frondini et al. (2009), which allowed for estimating the emissions per $\mathrm{kg}$ of geothermal steam and comparing them with the ones given in Baldacci et al. Baldacci et al. (2002). While the estimations calculated from Frondini et al. Frondini et al. (2009) (0.045-0.081 kg-CO2/ kg-steam) are in the same range than the values in Baldacci et al. Baldacci et al. (2002) (0.037 kg-CO2/ $\mathrm{kg}$-steam), the estimation calculated from the data of DiPippo DiPippo (2008) (0.005 kg-CO2/ $\mathrm{kg}$-steam) is one order of magnitude below, and was thus assumed as the minimum value, while the estimation from the data of Brown et al. Brown and Ulgiati (2002) (0.128 kg-CO2/kg-steam) was one order of magnitude above, and was taken as the maximum value. Due to the different geochemistry of EGS and hydrothermal systems, these data should however be updated once data are available for emissions from flash systems combined with EGS.

For the end-of-life phase, the $v_{k}$ quantities for cement and gravel used for well decommissioning are taken from Frick et al. Frick et al. (2010), and are as well expressed using Equation 2. No data were available for the working fluid losses from the binary cycle during the dismantling of the power plants. Thus, the value for heat pumps corresponding to $20 \%$ loss given in Saner 
et al. Saner et al. (2010) is assumed.

Tables 3, 4 and 5 of A summarize all the LCI elements for the construction, the operation and the end-of-life, respectively, with the parameters that allow for calculating them as a function of the geothermal system configuration, as well as with their reference quantities $v_{k}$ when this one is necessary. Table 6 of A gives the description of these parameters.

\subsubsection{Life Cycle Impact Assessment}

The LCIA step computes the environmental impact by aggregating the vector of the different elementary flows of emissions and extractions obtained for each element of the LCI in indicators of environmental significance, termed as impact categories. The aggregation is performed with an impact assessment method, which is a matrix containing the weightings for the elementary flows.

Here, two different impact assessment methods are used: the method of the Intergovernmental Panel on Climate Change (IPCC) 2007 Intergovernmental Panel on Climate Change (2007), used to quantify the global warming potential on a 100-year time-horizon in terms of CO2equivalents, and the Ecoindicator99-(h,a) Goedkoop and Spriensma (2000), a damage-oriented approach that measures the impact on the human health, the ecosystem quality and the nonrenewable resources, weighted and aggregated in a final single score.

Accounting for the life cycle perspective and for the multi-period aspects of the system operation, the final impacts per functional unit for each impact category of the two impact assessment methods are given by:

$$
I_{F U}=\frac{\sum_{p=1}^{n_{p}} \sum_{i=1}^{n_{e o}} \dot{I}_{O i, p} \cdot t_{p} \cdot t_{y r}+\sum_{i=1}^{n_{e c}} \max \left(I_{C i}\right)_{p}+\sum_{i=1}^{n_{e e}} \max \left(I_{E i}\right)_{p}}{\sum_{p=1}^{n_{p}} t_{p} \cdot t_{y r} \cdot \dot{f} u_{p}}
$$

where $\dot{I}_{O i, p}$ is the impact due to the operation phase for period $p$ of the LCI element $i$, $n_{e o}$ the number of LCI elements associated with operation phase, $I_{C i, p}$ the impact due to the construction phase for period $p$ of the LCI element $i, n_{e c}$ th number of LCI elements associated with construction phase, $I_{E i, p}$ the impact due to the end-of-life phase for period $p$ of the LCI element $i, n_{e e}$ the number of LCI elements associated with end-of-life phase, $t_{p}$ the time associated with period $p, t_{y r}$ the lifetime of the system, $\dot{f} u_{p}$ the quantity of functional unit involved during period $p$. For construction and end-of-life, a value is calculated independently for each period, and the maximal impact is then retained. 
In the present case, the functional unit being the EGS construction, operation and dismantling, and not a quantity of electricity or district heating, the denominator of Equation 8 is equal to one.

\subsection{Multi-objective optimization}

Three independent optimization objectives are selected.

1. The investment costs, to be minimized:

$$
\operatorname{Min} C_{i n v, t o t}=\frac{C_{i n v, E G S}(z)}{s}+\sum_{w=1}^{n_{w}} \max \left(C_{i n v, w}\left(z, \dot{Q}_{\text {max }}^{-}, x_{d}\right)\right)_{p}+C_{i n v, D H}\left(\dot{Q}_{\text {max }}^{-}\right)
$$

where $C_{i n v, E G S}$ are the investment costs linked with the sub-surface plant construction, function of the targeted exploitation depth $z$, as well accounting for the success factor $s$, $C_{i n v, w}$ is the investment cost of the equipment $w$, calculated for each period $p$ and for which the maximal value is taken, function of $z$, of the design size of the district heating $\dot{Q}_{\text {max }}^{-}$and of the other decision variables of the non-linear optimization problem $x_{d}$, and $C_{i n v, D H}$ is the investment costs of the district heating network expressed as a function of its nominal installed capacity.

2. The annual revenue, to be maximized:

$$
\begin{aligned}
& \operatorname{Max} R_{a n}=\sum_{p=1}^{n_{p}} t_{p} \cdot\left(c_{e}^{-} \cdot \dot{E}_{p}^{-}\left(z, \dot{Q}_{\text {max }}^{-}, x_{d}\right)+c_{q}^{-} \cdot \dot{Q}_{p}^{-}\left(\dot{Q}_{\text {max }}^{-}\right)\right. \\
& \left.-c_{o, E G S}(z)-\sum_{t=1}^{n_{t}} c_{o, t}\left(z, \dot{Q}_{\text {max }}^{-}, x_{d}\right)\right)
\end{aligned}
$$

where $t_{p}$ is the operating time associated with period $p, c_{e}^{-}$and $c_{q}^{-}$are the specific selling prices of electricity and district heating, respectively, $\dot{E}_{p}^{-} p$, in $\mathrm{MW}_{e}$ is the net electrical power produced at the operating conditions of period $p$ (consumption of geothermal pumps and cycle pumps is accounted for), $\dot{Q}_{p}^{-}$is the district heating power supplied during period $p$, calculated considering the installed capacity of the district heating network and the corresponding demand for the period, $c_{o, E G S}$ is the specific operating cost of the EGS and $c_{o, t}$ is the specific operating cost of conversion technology $t . c_{e}^{-}$and $c_{q}^{-}$are assumed to be $0.16 \mathrm{USD} / \mathrm{kWh}_{e}$ and $0.11 \mathrm{USD} / \mathrm{kWh}_{t h}$, respectively, which is representative of the average Swiss market conditions OFEN (2010), assuming no variation in the electricity and district heating prices over the EGS expected lifetime, assumed to be 30 years. 
3. The exergy efficiency of the conversion system, representing the ratio between the exergy services supplied and the exergy from the EGS entering the conversion system, to be maximized:

$$
\left.\operatorname{Max} \eta=\frac{\sum_{p=1}^{n_{p}} t_{p} \cdot\left(\dot{E}_{p}^{-}\left(z, \dot{Q}_{\text {max }}^{-}, x_{d}\right)+\dot{Q}_{p}^{-}\left(\dot{Q}_{\text {max }}^{-}\right) \cdot\left(1-\frac{T_{a}}{T_{D H, l m, p}}\right)\right.}{\sum_{p=1}^{n_{p}} t_{p} \cdot \dot{Q}_{E G S, p}^{+}\left(z, x_{d}\right) \cdot\left(1-\frac{T_{a}}{T_{E G S, l m, p(z)}}\right)}\right)
$$

where $\dot{Q}_{E G S, p}^{+}$is the available thermal power from the EGS during period $p, T_{a}$ is the ambient temperature, or temperature of the cold source, assumed to be $10^{\circ} \mathrm{C}$, and $T_{l m}$ is the logarithmic mean temperature of the heating or cooling requirement in ${ }^{\circ} \mathrm{K}$, calculated by:

$$
T_{l m}=\frac{T_{\text {in }}-T_{\text {out }}}{\ln \left(\frac{T_{\text {in }}}{T_{\text {out }}}\right)}
$$

where $T_{i n}$ is the inlet temperature of the hot source and $T_{\text {out }}$ is the outlet temperature at which the hot source is cooled. For the district heating, $T_{i n}$ is the supply temperature and $T_{\text {out }}$ is the return temperature. For the EGS, $T_{\text {in }}$ is the temperature at extraction well and $T_{\text {out }}$ is the reinjection temperature.

For each possible combination of conversion technologies and each proposed working fluid in the binary cycles, the trade-off between the three objectives is calculated by generating a Pareto front. The decision variables considered for the optimization problem are given in Table 2.4.

All the decision variables are generated using a multi-period strategy Gerber and Maréchal (2012), except for $z$ and $\dot{Q}_{\max }^{-}$that define the system size. Indeed, even if the district heating network installed capacity is fixed, it corresponds to a seasonal variation in the demand for four periods of the year: summer $\left(t_{p}=525 \mathrm{~h}\right)$, interseason $\left(t_{p}=3942 \mathrm{~h}\right)$, winter $\left(t_{p}=4205 \mathrm{~h}\right)$ and extreme winter $\left(t_{p}=88 \mathrm{~h}\right)$, the last one being used to calculate the installed capacity.

\subsection{Selection of final optimal configurations}

Since the multi-objective optimization results in a large number of optimal points, each one representing one configuration for the geothermal system, a selection of configurations has to be performed to classify the solutions. This is done for each cluster of technologies and working fluid by selecting one configuration each $500 \mathrm{~m}$ between 3000 and $10000 \mathrm{~m}$, and each $5 \mathrm{MW}_{t h}$ for the district heating network capacity from 0 to $60 \mathrm{MW}_{t h}\left(0 \mathrm{MW}_{t h}\right.$ meaning single electricity production). To select the final configuration at a given depth and district heating capacity, 


\begin{tabular}{|c|c|c|c|}
\hline Name & $\begin{array}{l}\text { Conversion } \\
\text { technology }\end{array}$ & Range & Unit \\
\hline EGS construction depth $z$ & all & $\begin{array}{l}{[3000} \\
10000]\end{array}$ & $\mathrm{m}$ \\
\hline $\begin{array}{l}\text { District heating network installed ca- } \\
\text { pacity } \dot{Q}_{\max }^{-}\end{array}$ & all & {$[0 ; 60]$} & $\mathrm{MW}_{t h}$ \\
\hline $\begin{array}{l}\text { Reinjection temperature of geothermal } \\
\text { water }\end{array}$ & all & {$[70 ; 130]$} & ${ }^{\circ} \mathrm{C}$ \\
\hline Expansion ratio in first flash drum & 1- and 2-flash & {$[0 ; 1]$} & - \\
\hline Expansion ratio in second flash drum & 2-flash & {$[0 ; 1]$} & - \\
\hline $\begin{array}{l}\text { Evaporation temperature of working } \\
\text { fluid }\end{array}$ & $\begin{array}{l}\text { ORC, } \\
\text { ORC-2 }\end{array}$ & {$[60 ; 135]^{\mathrm{a}}$} & ${ }^{\circ} \mathrm{C}$ \\
\hline $\begin{array}{l}\text { Temperature difference between ge- } \\
\text { ofluid and superheated working fluid }\end{array}$ & $\begin{array}{ll}\text { ORC, } & \text { ORC-d, } \\
\text { ORC-2, } & \text { ORC-s, } \\
\text { Kalina } & \end{array}$ & {$[5 ; 20]$} & ${ }^{\circ} \mathrm{C}$ \\
\hline $\begin{array}{l}\text { Temperature at which intermediate } \\
\text { draw-off is done }\end{array}$ & ORC-d & {$[20 ; 65]$} & ${ }^{\circ} \mathrm{C}$ \\
\hline $\begin{array}{l}\text { Splitting fraction between district heat- } \\
\text { ing and additional electricity produc- } \\
\text { tion }\end{array}$ & ORC-d & {$[0 ; 1]$} & - \\
\hline $\begin{array}{l}\text { Evaporation temperature of working } \\
\text { fluid at lower pressure }\end{array}$ & ORC-2 & {$[60 ; 135]^{\mathrm{a}}$} & ${ }^{\circ} \mathrm{C}$ \\
\hline $\begin{array}{l}\text { Splitting fraction between higher and } \\
\text { lower pressure evaporation }\end{array}$ & ORC-2 & {$[0 ; 1]$} & - \\
\hline $\begin{array}{l}\text { Higher pressure of the supercritical } \\
\text { working fluid }\end{array}$ & ORC-s & {$[34 ; 80]^{\mathrm{a}}$} & bar \\
\hline $\begin{array}{l}\text { Evaporation pressure of the working } \\
\text { fluid }\end{array}$ & Kalina & {$[32 ; 42]$} & bar \\
\hline $\begin{array}{l}\text { Condensation pressure of the working } \\
\text { fluid }\end{array}$ & Kalina & {$[6 ; 10]$} & bar \\
\hline $\begin{array}{l}\text { Ammonia molar fraction in the working } \\
\text { fluid }\end{array}$ & Kalina & {$[0.7 ; 0.85]$} & - \\
\hline
\end{tabular}

Table 2: Decision variables used for the MOO of the different combinations of conversion technologies

a adapted to the chosen working fluid

the payback period of the overall system is used, and other associated thermodynamic and environmental indicators are as well calculated. The payback period is calculated by:

$$
t_{p b}=\frac{C_{i n v, a n}}{R_{a n}}
$$

where $C_{i n v, a n}$ are the total investment costs of Equation 9, annualized using a lifespan of 30 years and an interest rate of $6 \%$, and $R_{a n}$ is the annual revenue calculated with Equation 10, considering a constant price for the energy services.

For analyzing the thermodynamic performance, the exergy efficiency of the conversion system (Equation 11) is used, accounting for the exergy delivered by the geothermal heat source with a varying reinjection temperature. 
For the environmental performance, the indicators are:

1. the yearly avoided CO2-equivalent emissions, using the IPCC07 impact method. The CO2 emissions for the full life-cycle of the EGS are compared with the production of the same services with a NGCC for electricity and a natural gas boiler for heating:

$$
\begin{aligned}
& E_{C O 2, a v}=\sum_{p=1}^{n_{p}}\left(t _ { p } \cdot \left(\dot{E}_{p}^{-} \cdot e_{C O 2, N G C C}+\dot{Q}_{p}^{-} \cdot e_{C O 2, N G B}\right.\right. \\
& \left.\left.-\sum_{i=1}^{n_{e o}} \dot{I}_{O i, p}\right)\right)-\left(\frac{\left.\sum_{i=1}^{n_{e} \max (} I_{C i}\right)_{p}+\sum_{i=1}^{n_{e}} \max \left(I_{E i}\right)_{p}}{t_{y r} \cdot s}\right)
\end{aligned}
$$

where $e_{C O 2, N G C C}$ and $e_{C O 2, N G B}$ are the specific $\mathrm{CO} 2$ emissions of electricity production from NGCC and for heating production from a natural gas boiler, respectively, taken from ecoinvent ${ }^{\circledR}$, and are equal to $0.425 \mathrm{~kg} \mathrm{CO} 2$-eq $/ \mathrm{kWh}_{e}$ and $0.241 \mathrm{~kg} \mathrm{CO} 2$-eq $/ \mathrm{kWh}_{t h}$, respectively.

2. the relative life cycle avoided impacts, using the single-score of the Ecoindicator99-(h,a). The impacts are again compared with the production of the same services. The best configuration of all is fixed as the reference (100\% of avoided impacts), and the other ones are then compared with this value.

\section{Results}

\subsection{Pareto curves}

Figure 4 shows some of the Pareto curves obtained for the tri-objective thermo-economic optimization. For readability, only a fraction of the potential combinations of technologies are displayed as examples to illustrate the behavior of the system configurations in the optimization: a single flash system, a binary cycle, and a single flash system with a bottoming ORC.

All the curves show a net trade-off between the investment cost and the annual revenue, and, in most of the cases, another trade-off between the exergy efficiency of the conversion system and the economic objectives. The effects of the EGS depth and of the district heating size on the trade-off between the investment and the revenue and on the other performance indicators are discussed in the next section. 


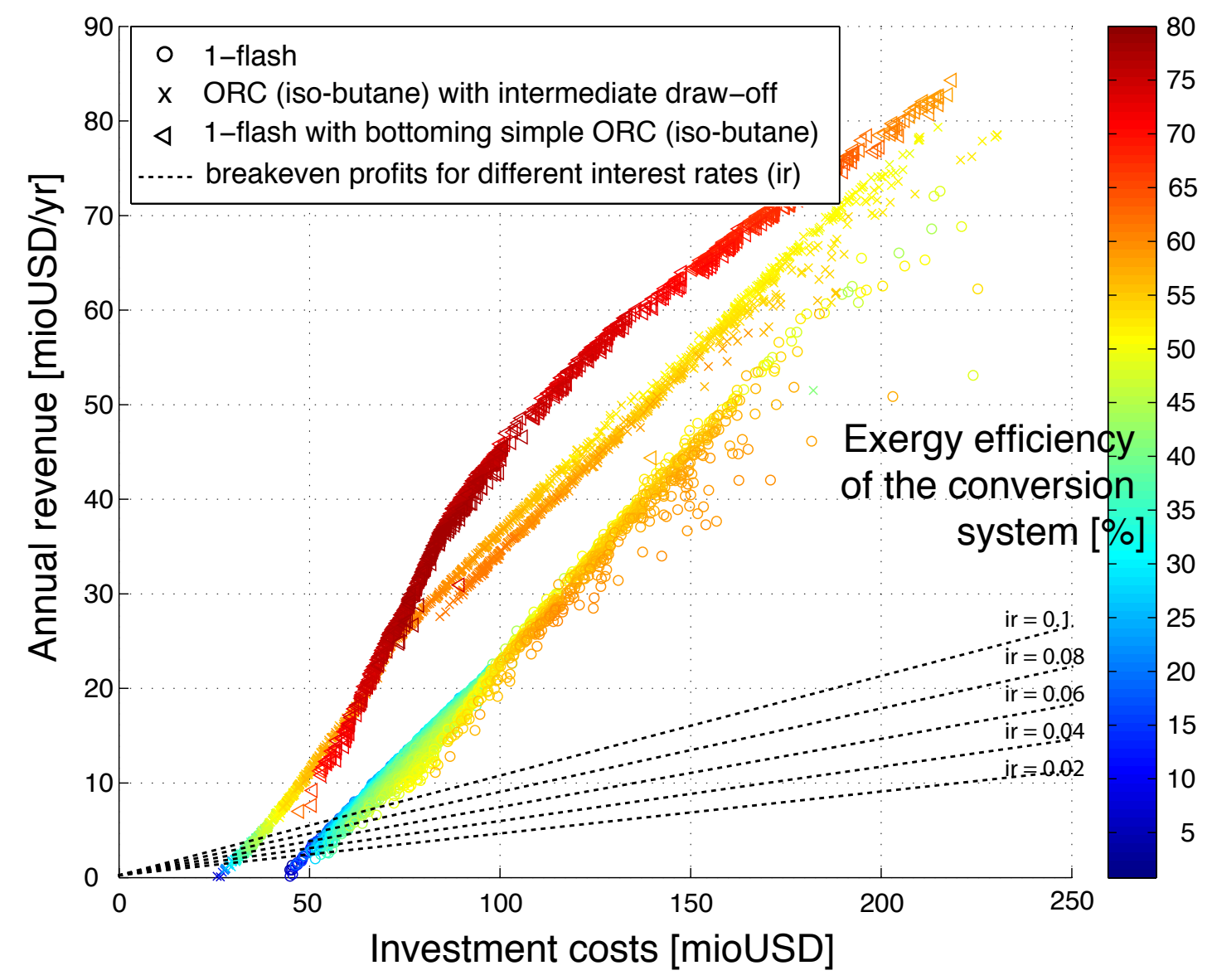

Figure 4: Examples of Pareto curves obtained by the tri-objective thermo-economic optimization, with the corresponding breakeven annual revenue for different interest rates

\subsection{Final optimal configurations}

The final optimal configurations, selected from the Pareto curves on the basis of the payback period (Equation 13), are displayed in Figure 5. The available thermal power from the EGS in function of the depth, assuming a minimal reinjection temperature of $70^{\circ} \mathrm{C}$, is as well displayed. The associated exergy efficiencies, avoided CO2 emissions and relative avoided life cycle impacts with Ecoindicator99-(h,a) are displayed in Figure 7, 8, and 10, respectively (to be discussed in the next subsections). For a more detailed analysis, supplementary indicators are available in B: the energy efficiency (Figure 13), the electrical efficiency (Figure 14) and the efficiency for the conversion of geothermal heat in district heating (Figure 15).

\subsubsection{Economic performance}

A detailed cost-benefit analysis of five typical configurations is displayed in Figure 6, for the configurations identified by a black circle on Figure 5. The operating conditions of these five configurations are summarized in Table 7, 8, 9, 10 and 11 of B . 


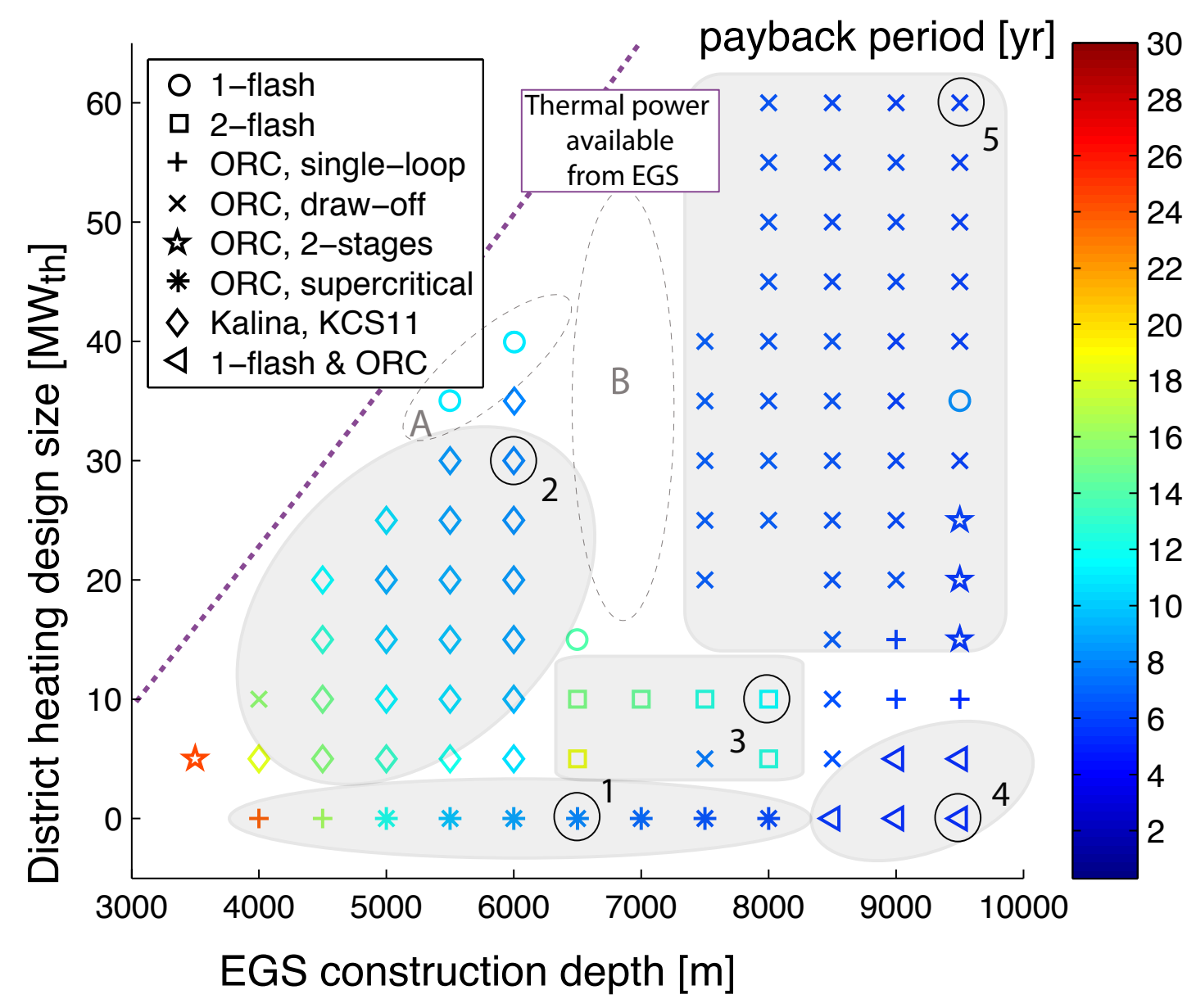

Figure 5: Best conversion technologies selected on the basis of the payback period, as a function of EGS depth and design size of district heating

From Figure 5, it appears first that with the economic assumptions and the geological conditions taken for the case study, deeper EGS from $7000 \mathrm{~m}$ to $10000 \mathrm{~m}$ are economically more attractive, due to a higher electricity production, as it can be seen in Figure 14, the deeper EGS showing higher electrical efficiencies. Only some of the Kalina configurations show similar performances for shallower wells, due to the cogeneration mode. From 7500m, the payback period does not decrease significantly anymore, despite the increased production of energy services. This is explained by the non-linear increase of the drilling costs of the EGS (see Figure 2). In the case of shallow EGS down to $6000 \mathrm{~m}$, the increase in the district heating installed capacity decreases the payback period and makes therefore CHP more competitive than single electricity production. In the case of deep EGS from 7500 to $10000 \mathrm{~m}$, there is no important change in the payback period with the increase of the district heating installed capacity, though increased district heating requirements decrease the electricity production. Regarding deep EGS, economics is therefore not necessarily the most important criterion regarding decision-making. In 
consequence, thermodynamic and environmental criteria can influence a lot on the final decision.

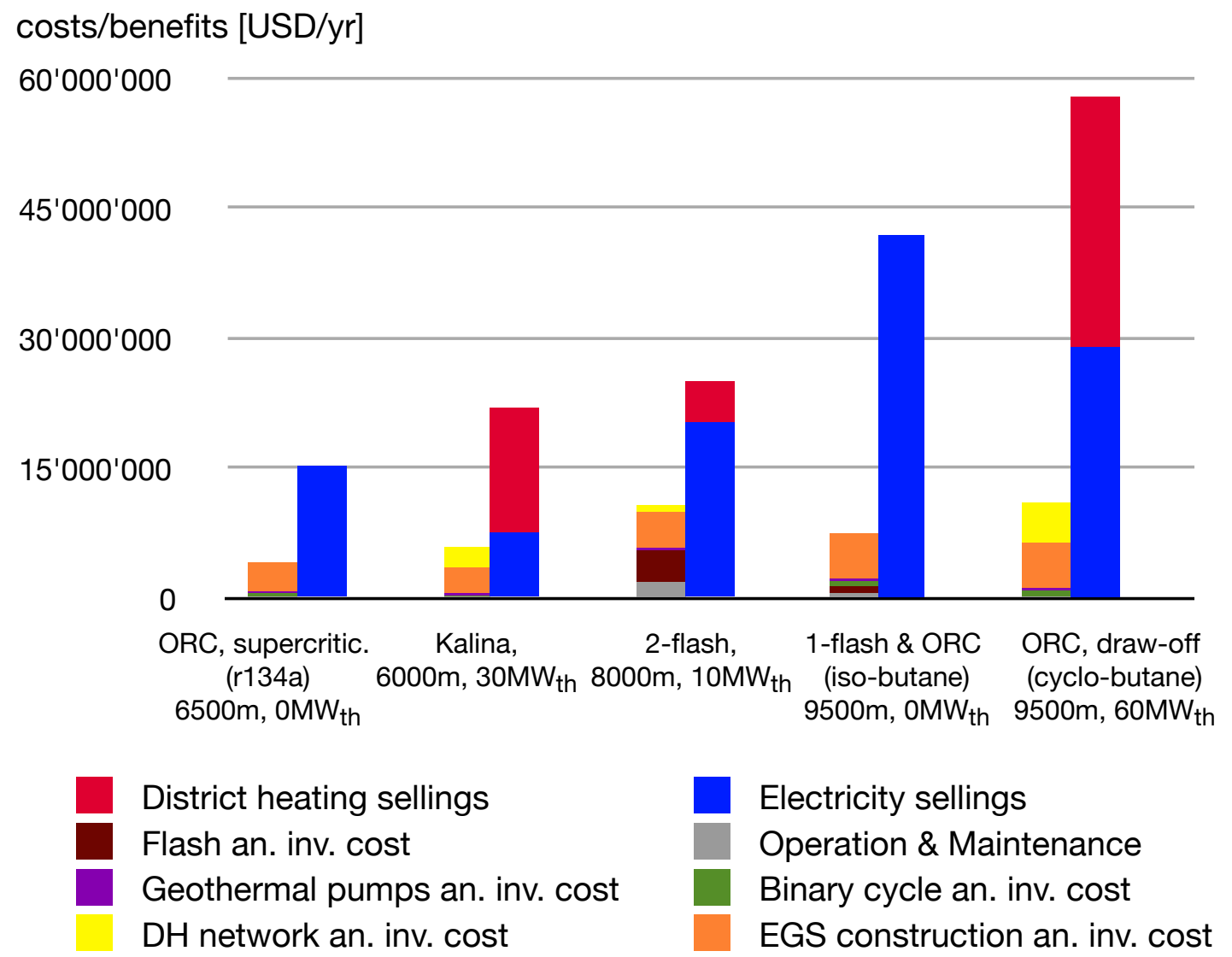

Figure 6: cost-benefit analysis on a yearly basis of 5 typical configurations from Figure 5

On Figure 5, five major zones can be distinguished, each one of them illustrated by a configuration in Figure 6:

1. EGS (4000-8000m) for electricity production only with an ORC using R134a(Table 7): the selected best technology is an ORC with a single-loop in the shallowest depths, and at larger depths a supercritical ORC. It is characterized by the lowest investment costs and the lowest revenue.

2. EGS (4500-6000m) for cogeneration (5-35 $\left.\mathrm{MW}_{t h}\right)$ with a Kalina cycle (Table 8): in the case of these configurations, the payback period decreases with an increased design size of the district heating, since the district heating plays the role of the cold source in the Kalina cycle producing electricity, as illustrated by the examplary integrated exergy composite curve Maréchal and Kalitventzeff (1996) of the Kalina cycle in Figure 16 in B. There is no trade-off between the two services in this case. Two configurations in this zone with large district heating networks (zone A on Figure 5) use a flash system. Indeed, at these 
depths, the temperature is low for electricity production using a flash system. Thus, using the waste heat from the liquid part of the flash for district heating before reinjection allows for an increase of the efficiency and makes this technology competitive.

3. EGS (6500-8000m) for cogeneration (5-15 $\left.\mathrm{MW}_{t h}\right)$ with a flash system (Table 9): in this range, large CHP systems (zone B on Figure 5) are not interesting when compared with electricity production or small CHP systems. The Kalina cycle is not selected anymore by the optimizer, because of the increased exergy losses beyond $6000 \mathrm{~m}$ (represented by the yellow area in the integrated composite curve of the cycle, in Figure 16). For other cycles, the solutions at these depths were suboptimal and not kept by the optimizer. Indeed, for a configuration in this range of depths with a large district heating network, better exergy efficiency and revenue can be achieved for the same investment costs by drilling deeper to reach a higher temperature and favoring electricity production, which saves the investment of the district heating. The temperature is high enough for flash systems, which are favored for small CHP systems since it valorizes the waste heat before reinjection without penalizing the electricity production.

4. EGS (8500-10000m) for electricity production only with a flash system and a bottoming ORC (Table 10): in this range, the thermal power from the liquid part of the flash system is sufficient to use a bottoming ORC, which allows for increasing the electricity output and decreasing the size of the flash system and its related investment.

5. EGS (7500-10000m) for cogeneration (10-60 $\left.\mathrm{MW}_{t h}\right)$ with an ORC (Table 11): these configurations have the largest investment costs due to the depth of the EGS and to the district heating capacity, but generate the highest revenue, though they do not increase the exergy efficiency and increase the investment costs. The selected technology is in majority an ORC with an intermediate draw-off, using the district heating as part of the cold source. Different working fluids are selected in function of the depth and of the district heating requirements (iso-butane, cyclo-butane, n-butane, iso-pentane, pentane).

\subsubsection{Thermodynamic performance}

The exergy efficiency of the conversion system associated with the optimal economic configurations is displayed in Figure 7.

The highest efficiencies of around $75 \%$ are achieved with a deep EGS between $8500 \mathrm{~m}$ and 


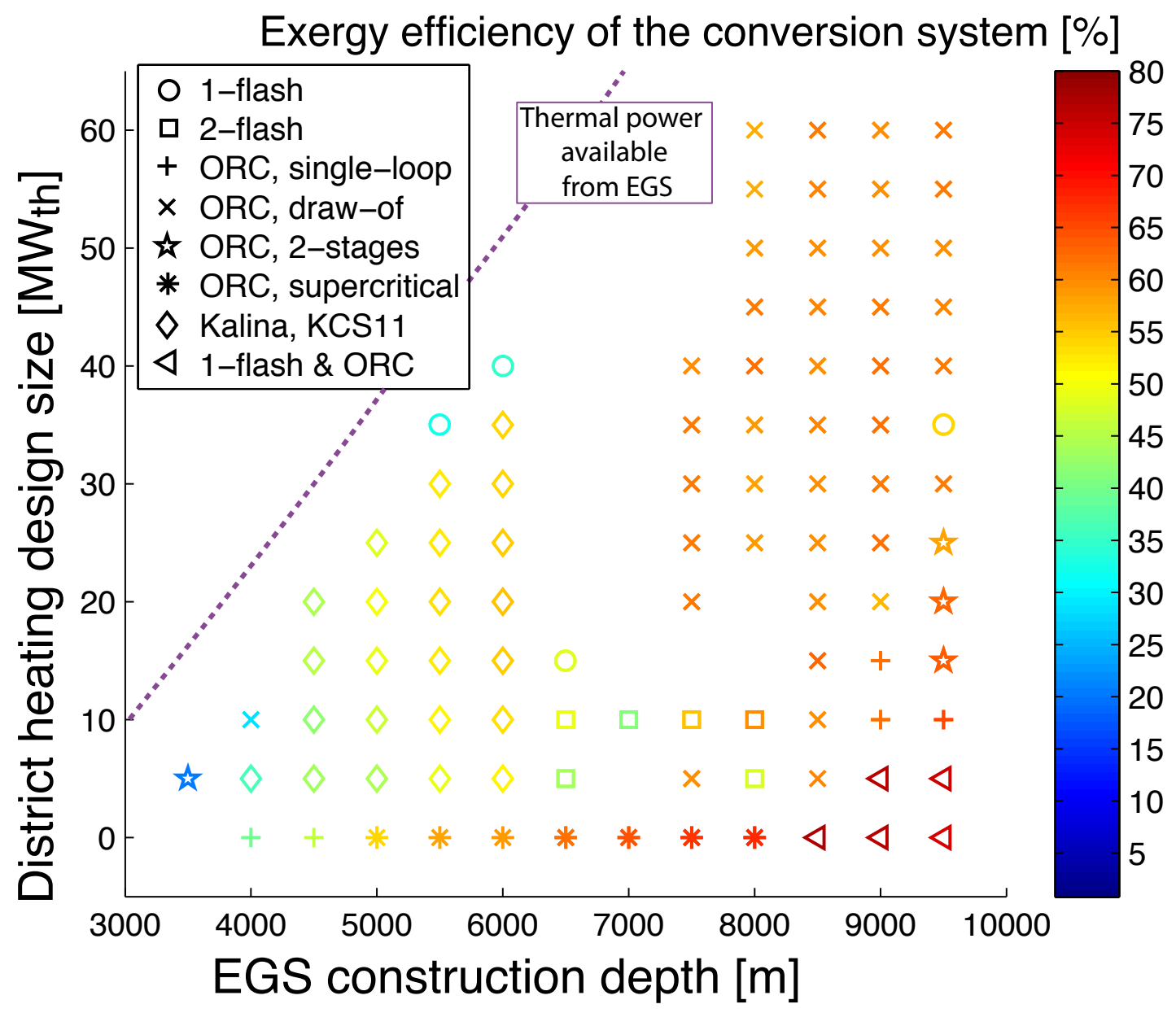

Figure 7: Exergy efficiencies of the conversion system associated with the best configurations of Figure 5

9000m using a single-flash system with a bottoming ORC, almost exclusively for electricity production. In the case of CHP systems, the highest efficiencies of around $60 \%$ are achieved by an ORC with an intermediate draw-off between $7500 \mathrm{~m}$ and $9500 \mathrm{~m}$. It remains relatively constant in this range, due to the switches in the choice of the working fluid in function of the depth.

\subsubsection{Environmental performance}

Avoided CO2 emissions The yearly-avoided CO2 emissions associated with the optimal economic configurations are displayed in Figure 8. A detailed $\mathrm{CO} 2$ balance is displayed in Figure 9 for the configurations identified by a black circle in Figure 8.

The yearly-avoided CO2 emissions, calculated on a life cycle basis, increase with the EGS depth. Though there is a high variation between the shallowest and the deepest configuration, none of the selected optimal configurations has a negative $\mathrm{CO} 2$ balance. Like the economic calculations, this is however only valid for the geological conditions assumed in the present case. 


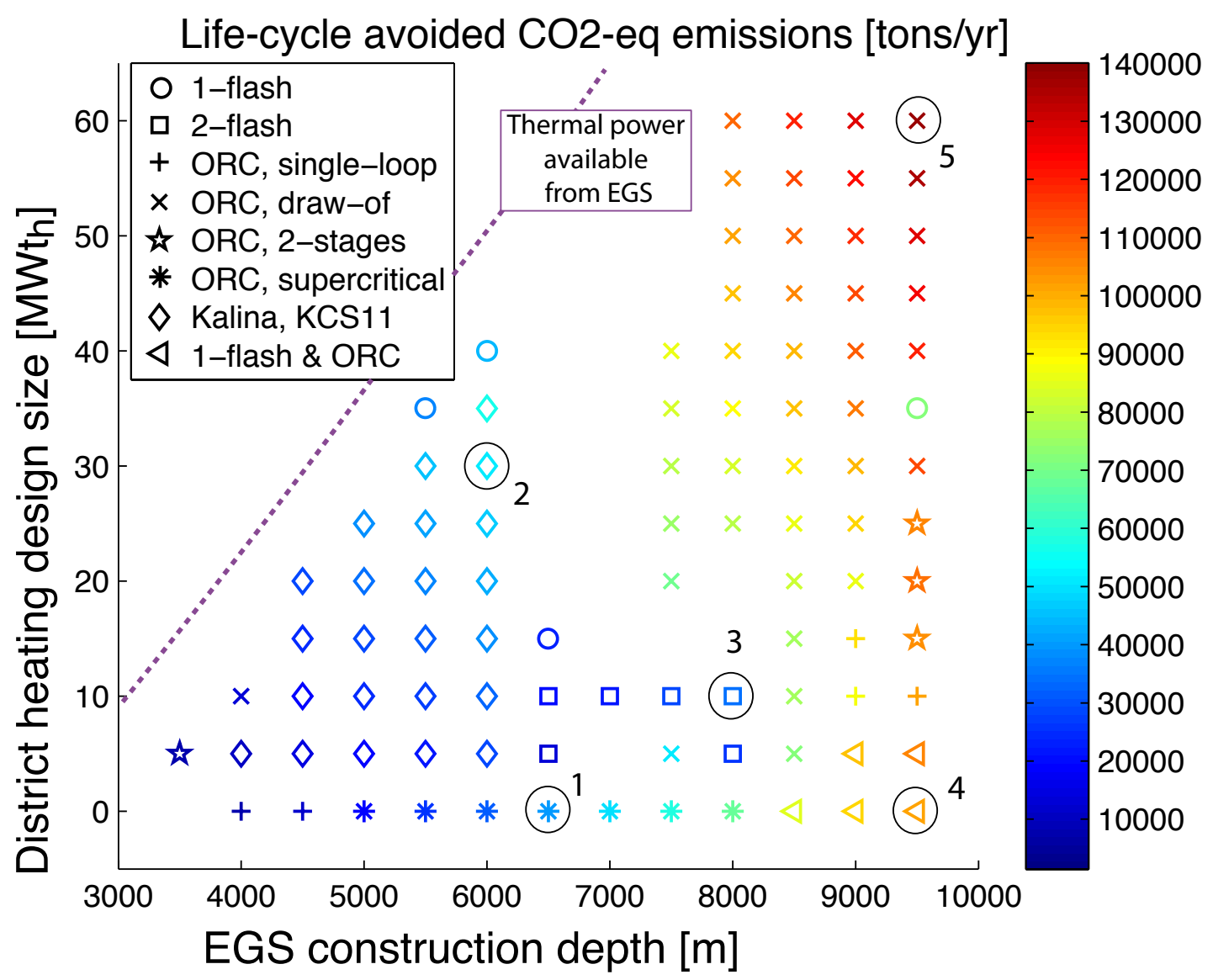

Figure 8: Yearly avoided CO2 emissions associated with the best configurations of Figure 5

As shown by Figure 9, when compared with the beneficial impacts from the substitution of energy services, the harmful impacts due to the construction of the EGS and of the power plant are insignificant in the present case study.

From $4000 \mathrm{~m}$ to $6000 \mathrm{~m}$ and from $7500 \mathrm{~m}$ and $9500 \mathrm{~m}$, the avoided $\mathrm{CO} 2$ emissions at a given depth increase with the district heating capacity. Examples are the configuration 2 with a Kalina cycle and the configuration 5 with an ORC integrating an intermediate draw-off, which has the highest avoided $\mathrm{CO} 2$ emissions. Oppositely, between $6000 \mathrm{~m}$ and $7500 \mathrm{~m}$ the configurations for single electricity production with a binary cycle, like the configuration 1 with a supercritical ORC, have higher avoided $\mathrm{CO} 2$ emissions than CHP systems using a flash system, like the configuration 3 , since flash systems directly use the geothermal steam that contains $\mathrm{CO} 2$ and other non-condensable gases, released to the atmosphere at the condensers. As shown by the maximum potential $\mathrm{CO} 2$ emissions on the graph, the balance might even be negative if EGS using flash systems have comparable $\mathrm{CO} 2$ emissions to the maximum value of some existing hydrothermal systems. However, this particular aspect has to be verified once reliable data are available for the emissions from flash systems combined with EGS. In the present case, the use 


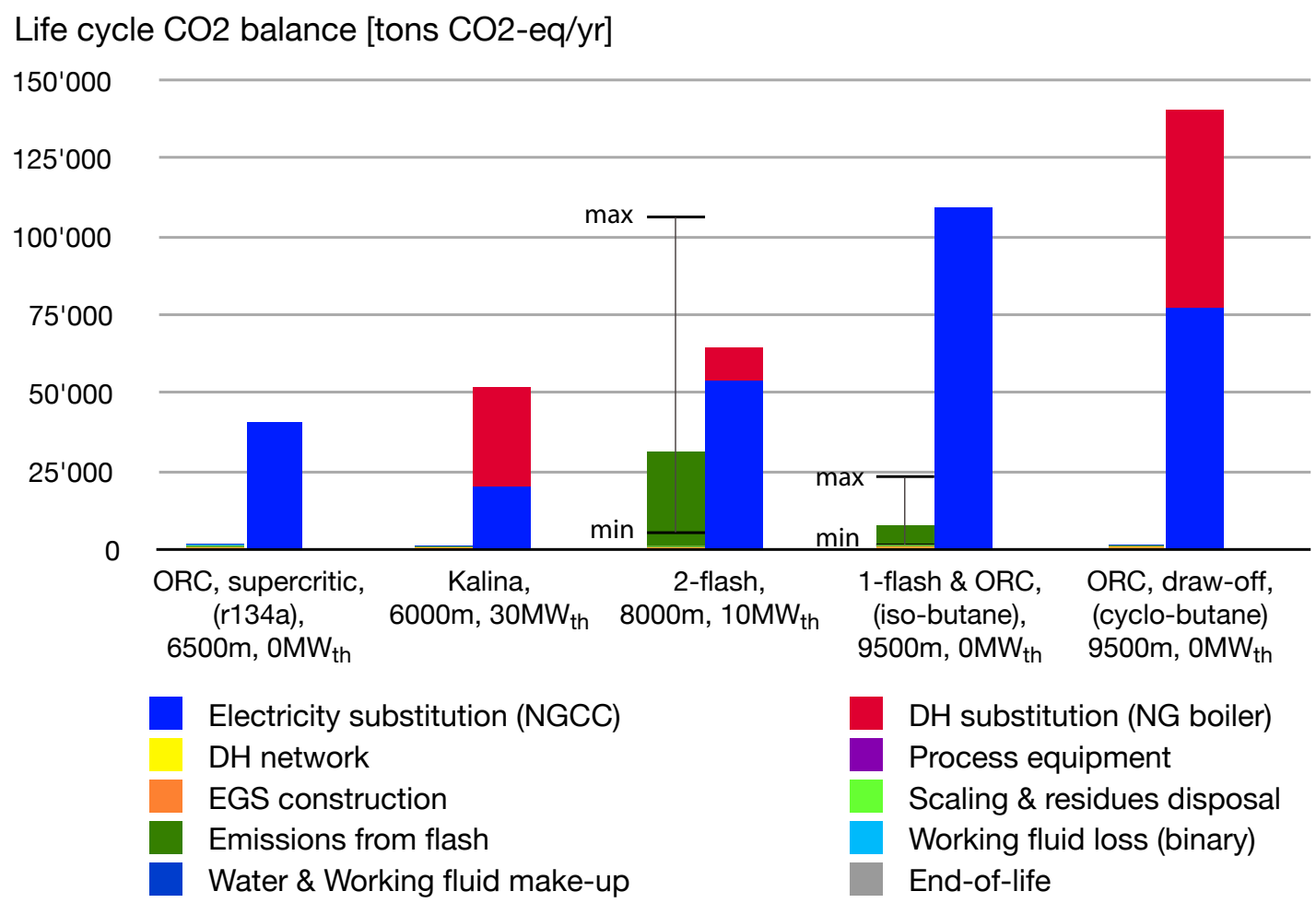

Figure 9: $\mathrm{CO} 2$-equivalent balance on a yearly basis for 5 typical configurations of Figure 8 . Minimum and maximum values for the $\mathrm{CO} 2$ emissions from the flash condensers are shown.

of a bottoming binary cycle with a single flash system (see configuration 4) allows for increasing significantly the electricity output, and for decreasing the emissions from the flash, which has a smaller size and uses therefore less steam.

Though electricity production avoids more $\mathrm{CO} 2$ than district heating on the basis of the kWh delivered, CHP systems with large district heating networks have higher energy efficiencies due to an increased district heating production, and therefore avoid more $\mathrm{CO} 2$ than the single electricity production (see Figures 13 to 15 of B)

Instead of using the linear model of Frick et al. Frick et al. (2010) for the impact scaling as a function of the depth for the EGS construction and its end-of-life, the exponent used for the non-linear scaling of the drilling costs, equal to 1.3879, can be used. Indeed, the analogy between the costs and the environmental impacts has been validated for process equipment in Gerber et al. (2011) and could as well probably be applied for the auxiliary materials depending on EGS depth. However, the difference in the total avoided CO2 emissions with the linear scaling is at the most an increase of $1.5 \%$ if the power scaling is applied, the impact being dominated by the substitution of energy services and the emissions from the flash systems. 
Ecoindicator99-(h,a) The relative life-cycle avoided impacts calculated with Ecoindicator99$(\mathrm{h}, \mathrm{a})$, in percentage of the best configuration $\left(9500 \mathrm{~m}\right.$ and $\left.60 \mathrm{MW}_{t h}\right)$, are presented in Figure 10.

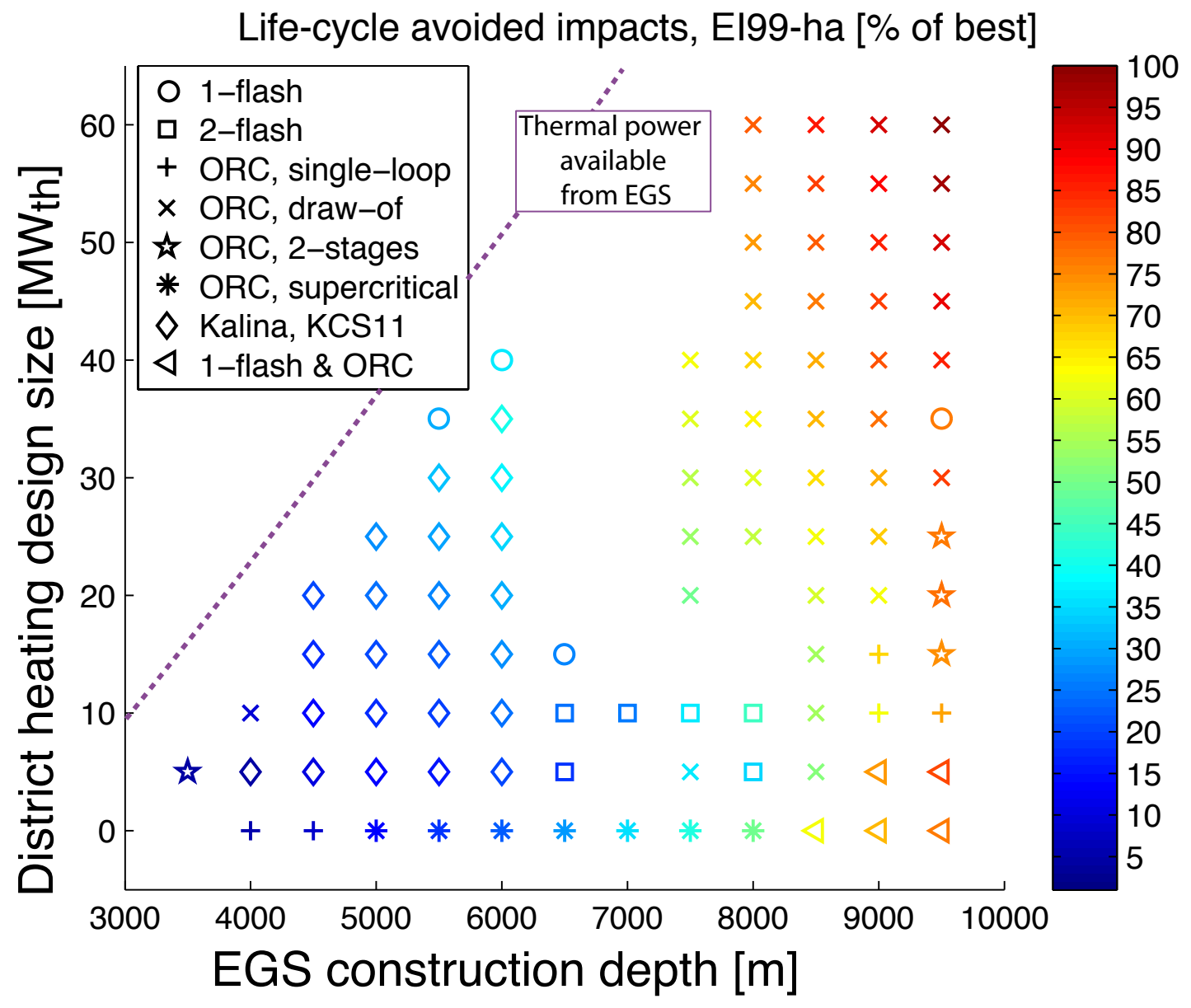

Figure 10: Relative life cycle avoided impacts with Ecoindicator99-(h,a) associated with the best configurations of Figure 5

Here again, though the relative differences are important, no configuration has a negative environmental balance. The avoided impacts show a similar behavior to the avoided CO2 emissions, increasing with depth and with district heating capacity. However, unlike for the avoided $\mathrm{CO} 2$ emissions, there is a less clear difference between flash systems and binary cycles in favor of the latter, because the Ecoindicator99-(h,a) weighs more strongly the substitution of natural gas, diluting thus the impact of $\mathrm{CO} 2$ emissions from flash systems.

Comparison with thermo-economic criteria The two environmental criteria can be compared with the other economic and thermodynamic performance indicators (i.e. payback period and exergy efficiency of the conversion system). In the shallowest range of EGS depths, from $4000 \mathrm{~m}$ to $6000 \mathrm{~m}$, all the decision criteria favor the EGS at $6000 \mathrm{~m}$ with a Kalina cycle and a 
district heating network with an installed capacity between 20 and $35 \mathrm{MW}_{t h}$. However, in the deepest range between $7500 \mathrm{~m}$ and $9500 \mathrm{~m}$, integrating environmental criteria in the decisionmaking procedure leads to favor solutions that would not be considered if only the payback period and the exergy efficiency of the conversion system were considered. Indeed, these thermoeconomic criteria lead rather to favor the single electricity production over CHP systems. If the best configuration from an environmental point of view, i.e. configuration 5 (ORC-d at 9500m and $60 \mathrm{MW}_{t h}$ ), is compared in relative terms with the configuration 4 (flash system and bot-

toming ORC at $9500 \mathrm{~m}$ for single electricity production), the penalty is of $11 \%$ for the payback period and of $17 \%$ in terms of exergy efficiency. However, the relative improvements in terms of environmental performance are more important: 37\% for the avoided CO2 emissions, and 31\% for the avoided life-cycle impacts calculated with Ecoindicator99-(h,a). Therefore, one could argue that the environmental performances outweigh the thermo-economic ones, and that the configurations with CHP having a large district heating network capacity should be favored for the construction of deep EGS.

\subsection{Sensitivity analysis}

All types of geothermal systems are subject to high uncertainty because of the high variability of natural and market conditions. This can potentially have important effects on the construction of the EGS, in terms of drilling costs and energy required for the drilling and the reservoir enhancement. It is therefore important to test the sensitivity of the previously presented results to an increase in the costs and in the required energy and materials for construction, equivalent to a reduction in the success factor in creating the EGS, which was assumed to be $100 \%$ in the previous calculations. The sensitivity to the success factor is realized by calculating the 5 configurations for successive values of the success factor from $100 \%$ to $10 \%$, the latter representing the average success factor in the oil industry Dones et al. (2007). The effect of the reduction of the success factor on the payback period is displayed in Figure 11.

If the success factor drops to $50 \%$, all the configurations are still attractive, though there is a significant increase in the payback period of around 4 years. The payback period of all configurations increases then strongly, though slightly less fast for the configurations with CHP than for the single electricity production. At $10 \%$ of success, none of the configurations has a payback period inferior to the assumed lifetime for the EGS. If the same analysis is done on the avoided CO2-emissions and on the impacts calculated with Ecoindicator99-(h,a), no significant 


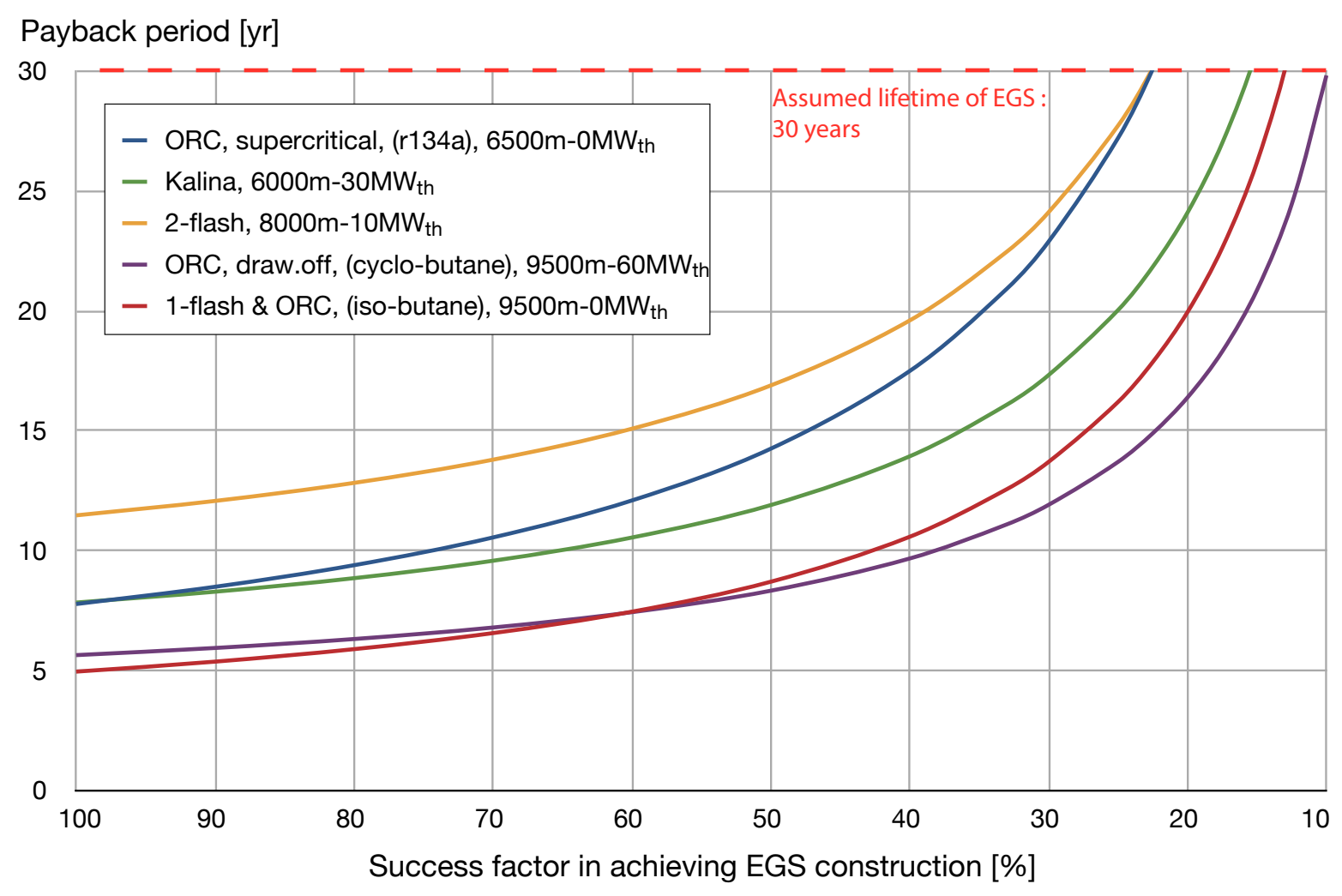

Figure 11: Sensitivity of the success factor on the payback period for the different configurations

change is observed with the decrease of the success factor. This is because the harmful impacts from EGS construction are insignificant when compared with the avoided impacts from electricity production, district heating and with the emissions from flash systems (see Figure 9).

The same analysis can be done on the selection of final optimal configurations. Figure 12 shows how this selection and the associated payback period evolve with more pessimistic estimates for success factors of $50 \%$ and $20 \%$. They can be compared with Figure 5, assuming a $100 \%$ success factor for a future mature EGS technology.

At $50 \%$ of success, no configuration has a payback period inferior to 10 years and EGS construction in the shallowest range is no longer attractive anymore. The most attractive configurations remain the deep EGS from 7500-10000m, with or without CHP, as well as the configurations from 5500-6000m using a Kalina cycle and a large CHP system with a district heating capacity of 30-35 $\mathrm{MW}_{t h}$. At $20 \%$ of success, most of the selected configurations have a payback period around 20 years or higher. In this case, CHP from deep EGS becomes clearly more attractive then single electricity production. The few configurations selected from $5000 \mathrm{~m}$ to $6000 \mathrm{~m}$ have a payback period very close to 30 years, which makes them economically unattractive. 

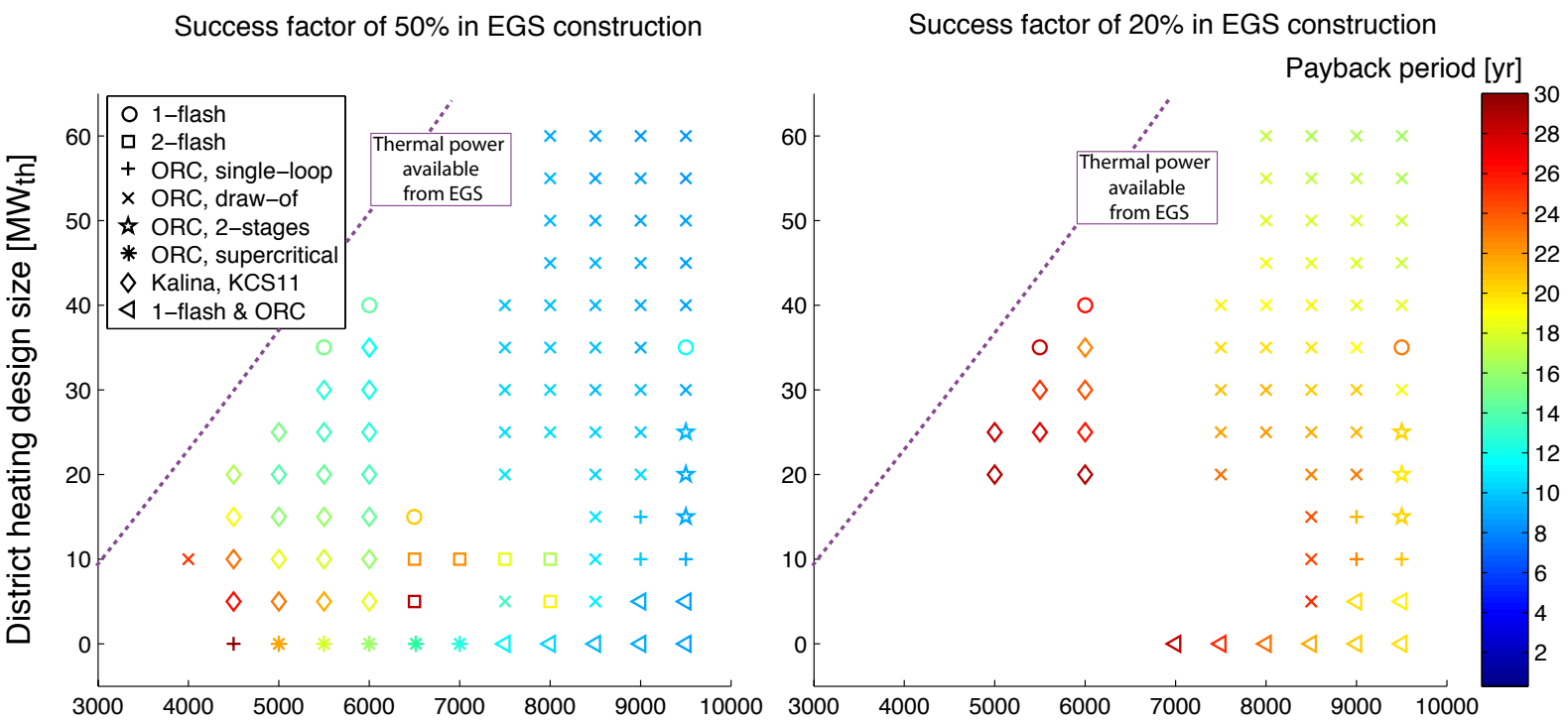

EGS construction depth [m]

Figure 12: Best technologies selected on the basis of the payback period for a $50 \%$ and $20 \%$ success factor in achieving EGS sub-surface plant construction

\section{Conclusions}

A systematic methodology has been presented for the conceptual design of geothermal energy conversion systems, considering combined heat and power production. The method includes economic, thermodynamic and life-cycle environmental indicators, all of them being expressed as a function of the conversion technology and of the system configuration. It has been applied to determine the optimal configurations of a mature EGS technology in the geological conditions and market context of Switzerland.

The results of the case study in terms of economic, thermodynamic and environmental performance reflect the possible variety of the system designs: EGS construction depth, installed capacity of the district heating network, choice of the conversion cycle and operating conditions. The following major conclusions can be drawn from the results of this case study:

- All the optimal economic configurations have a beneficial environmental balance, both in terms of avoided CO2-equivalent emissions and life-cycle avoided impacts. However, the variations among the optimal configurations are important, depending on the EGS construction depth, on the district heating design size and on the technology choice.

- In the shallowest range of depths from $3500 \mathrm{~m}$ down to $6000 \mathrm{~m}$, the economic, thermodynamic and environmental performances all favor the configurations with a Kalina cycle, an EGS construction depth around 5500 and $6000 \mathrm{~m}$, and a district heating network capacity 
between 20 and $35 \mathrm{MW}_{t h}$. Compared with the solutions with CHP, the single electricity production has less attractive performances.

- In deeper ranges between $7500 \mathrm{~m}$ and $9500 \mathrm{~m}$, the payback period of the system decreases slightly for systems with single electricity production, using a flash system with a bottoming ORC. However, the variations in terms of exergy efficiency and of environmental impacts are more important. If the exergy efficiency criterion is considered, single electricity production with a single flash system and a bottoming ORC should be favored. If the environmental criterion is considered, the deepest EGS with the largest district heating network should be favored, using an ORC with an intermediate draw-off. At $9500 \mathrm{~m}$, the combined heat and power production with a district heating installed capacity of $60 \mathrm{MW}_{\text {th }}$ features a payback period that is $11 \%$ higher than the one of the single electricity production. At the same time, it leads to an exergetic performance that is of $17 \%$ lower. However, the CHP solution leads to an increase of $37 \%$ of the avoided CO2 emissions and $31 \%$ of the avoided impact with Ecoindicator99-(h,a), respectively. The present study demonstrates therefore that integrating the LCA in the decision making process can lead to take different decisions when compared with the conventional thermo-economic analysis.

- If the success factor in achieving EGS construction decreases or if the investment costs increase, the economic performance is highly affected while the environmental performance, dominated by the avoided impacts from electricity and district heating production, does not change significantly.

Though the approach is promising, the methodology needs to be extended to include geological and economic uncertainties. Another aspect to be improved are the data used for the environmental performance, since it is presently not possible to model with acceptable confidence the required material and energy flows for the drilling and reservoir enhancement as a function of the geology.

\section{Acknowledgements}

The present study represents part of the research project Geotherm funded by the Competence Center Environment and Sustainability of the ETH Domain (CCES). 


\section{References}

Lund, J., Bertani, R.. Worldwide Geothermal Utilization 2010. In: Geothermal Resources Council Transactions; vol. 34. 2010, p. 182-185.

IEA, . Technology Roadmap - Geothermal Heat and Power. Tech. Rep.; International Energy Agency; Paris, France; 2011.

Franco, A., Vaccaro, M.. An integrated "Reservoir-Plant" strategy for a sustainable and efficient use of geothermal resources. Energy 2012;37:299-310.

Franco, A., Villani, M.. Optimum design of binary cycle power plants for water-dominated, medium-temperature geothermal fields. Geothermics 2009;38:379-391.

Hettiarachchi, H., Golubovic, M., Worek, W., Ikegami, Y.. Optimum design criteria for an Organic Rankine cycle using low-temperature geothermal heat sources. Energy 2007;32:16981706 .

Saleh, B., Koglbauer, G., Wendland, M., Fischer, J.. Working fluids for low-temperature organic Rankine cycles. Energy 2007;32:1210-1221.

Heberle, F., Brüggemann, D.. Exergy based fluid selection for a geothermal Organic Rankine Cycle for combined heat and power generation. Applied Thermal Engineering 2010;30:13261332 .

Guo, T., Wang, H., Zhang, S.. Selection of working fluids for a novel low-temperature geothermally-powered ORC based cogeneration system. Energy Conversion and Management 2011a:52:2384-2391.

Guo, T., Wang, H., Zhang, S.. Fluids and parameters optimization for a novel cogeneration system driven by low-temperature geothermal sources. Energy 2011b;36:2639-2649.

DiPippo, R.. Second Law assessment of binary plants generating power from low-temperature geothermal fluids. Geothermics 2004;33:565-586.

Kanoglu, M., Dincer, I.. Performance assessment of cogeneration plants. Energy Conversion and Management 2009;50:76-81.

Coskun, C., Oktay, Z., Dincer, I.. Modified exergoeconomic modeling of geothermal power plants. Energy 2011;36:6358-6366. 
Ganjehsarabi, H., Gungor, A., Dincer, I.. Exergetic performance analysis of Dora II geothermal power plant in Turkey. Energy 2011;:http://dx.doi.org/10.1016/j.energy.2012.02.039.

Ozgener, L., Hepbasli, A., Dincer, I., Rosen, M.. Exergoeconomic analysis of geothermal district heating systems: A case study. Applied Thermal Engineering 2007;27:1303-1310.

Shengjun, Z., Huaixin, W., Tao, G.. Performance comparison and parametric optimization of subcritical Organic Rankine Cycle (ORC) and transcritical power cycle system for lowtemperature geothermal power generation. Applied Energy 2011;88:2740-2754.

Astolfi, M., Xodo, L., Romano, M., Macchi, E.. Technical and economical analysis of a solar-geothermal hybrid plant based on Organic Rankine Cycle. Geothermics 2011;40:58-68.

Chamorro, C., Mondejar, M., Ramos, R., Segovia, J., Martin, M., Villamanan, M.. World geothermal production status: Energy, environmental and economic status of high enthalpy technologies. Energy 2012;42:10-18.

Lazzaretto, A., Toffolo, A., Manente, G., Rossi, N., Paci, M.. Cost Evaluation of organic Rankine cycles for Low temperature geothermal sources. In: Proceedings of the 24th International Conference on Efficiency, Cost, Optimization, Simulation and Environmental Impact of Energy Systems. 2011, p. 3854-3868.

Gerber, L., Maréchal, F.. Defining optimal configurations of geothermal systems using process design and process integration techniques. Applied Thermal Engineering 2012;43:29-41.

Evans, A., Strezov, V., Evans, T.. Assessment of sustainability indicators for renewable energy technologies. Renewable and Sustainable Energy Reviews 2009;13:1082-1088.

ISO, . Environmental management - Life Cycle Assessment - Principles and framework. International Standard, ISO 14’040.; 2006a.

ISO, . Environmental management - Life Cycle Assessment - Requirements and guidelines. International Standard, ISO 14'044.; 2006b.

DiPippo, R.. Geothermal energy: electricity generation and environmental impact. Energy Policy 1991;19:798-807.

Mock, J., Tester, J., Wright, P.. Geothermal energy from the earth: Its potential impact 
as an environmentally sustainable resource. Annual Review of Energy and the Environment 1997;22:305-356.

Rybach, L.. Geothermal energy: Sustainability and the environment. Geothermics 2003;32:463470.

Kristmannsdottir, H., Armannsson, H.. Environmental aspects of geothermal energy utilization. Geothermics 2003;32:451-461.

Saner, D., Juraske, R., Kübert, M., Blum, P., Hellweg, S., Bayer, P.. Is it only CO2 that matters? A life cycle perspective on shallow geothermal systems. Renewable and Sustainable Energy Reviews 2010;14:1798-1813.

Santoyo-Castelazo, E., Gujba, H., Azapagic, A.. Life cycle assessment of electricity generation in Mexico. Energy 2011;36:1488-1499.

Frick, S., Kaltschmitt, M., Schröder, G.. Life cycle assessment of geothermal binary power plants using enhanced low-temperature reservoirs. Energy 2010;35:2281-2294.

Gerber, L., Gassner, M., Maréchal, F.. Systematic Integration of LCA in process systems design: Application to combined fuel and electricity production from lignocellulosic biomass. Computers \& Chemical Engineering 2011;:1265-1280.

Linnhoff, B., Townsend, D., Boland, D., Hewitt, G., Thomas, B., Guy, A., et al. User Guide on Process Integration for the Efficient Use of Energy. Rugby, Warks, England: The Institution of Chemical Engineers; 1982.

Maréchal, F., Kalitventzeff, B.. Process integration: Selection of the optimal utility system. Computers \& Chemical Engineering 1998;22:S149-S156.

Turton, R., Bailie, R., Whiting, W., Shaiewitz, J.. Analysis, synthesis and design of chemical processes. New Jersey, USA: Prentic Hall; 1998.

Ulrich, G.D.. A guide to chemical engineering process design and economics. New York, USA: Wiley; 1996.

DiPippo, R.. Geothermal Power Plants: Principles, Applications, Case Studies and Environmental Impacts, Second Edition. Oxford, UK: Butterworth-Heinemann c/o Elsevier; 2008. 
Molyneaux, A., Leyland, G., Favrat, D.. Environomic multi-objective optimisation of a district heating network considering centralized and decentralized heat pumps. Energy 2010;35:751758.

Cuenot, N., Faucher, J.P., Fritsch, D., Genter, A., Szablinski, D.. The European EGS project at Soultz-sous-Forêts: from extensive exploration to power production. In: IEEE Power and Energy Society 2008 General Meeting: Conversion and Delivery of Electrical Energy in the 21st Century, PES, art. no. 4596680. 2008,.

Tester, J., Anderson, B., Batchelor, A., Blackwell, D., DiPippo, R., Drake, E., et al. The Future of Geothermal Energy - Impact of Enhanced Geothermal Systems (EGS) on the United States in the 21st Century. Tech. Rep.; Massachusetts Institute of Technology; Cambridge, Massachusetts, USA; 2006.

Haring, M.. Deep heat mining: Development of a cogeneration power plant from an enhanced geothermal system in Basel, Switzerland. In: Geothermal Resources Council Transactions; vol. 28. 2004, p. 219-222.

Sprecher, J.. Tridimensional modeling of the deep geology of the Molassic Plateau of Western Switzerland. Master thesis effectuated at Ecole Polytechnique Fédérale de Lausanne, Switzerland; 2011.

Mlcak, H.. Kalina Cycle Concepts for Low Temperature Geothermal. In: Geothermal Resources Council Transactions. 2002, p. 707-713.

Belsim, . www.belsim.com, official website of the Belsim company, Awans, Belgium, last date of access: $18.10 .2011 ; 2011$.

Minder, R., Ködel, J., Schädle, K.H., Ramsel, K., Girardin, L., Maréchal, F.. Energy conversion processes for the use of geothermal heat. Tech. Rep.; Swiss Federal Office of Energy; Bern, Switzerland; 2007.

Girardin, L., Maréchal, F., Dubuis, M., Calame-Darbellay, N., Favrat, D.. EnerGis: A geographical information based system for the evaluation of integrated energy conversion systems in urban areas. Energy 2010;35:830-840.

Frischknecht, R., Jungbluth, N., Althaus, H.J., Doka, G., Dones, R., Heck, T., et al. The 
ecoinvent database: Overview and methodological framework. International Journal of Life Cycle Assessment 2005;10:3-9.

Portier, S., Vuataz, F.D., Nami, P., Sanjuan, B., Gérard, A.. Chemical stimulation techniques for geothermal wells: experiments on the three-well EGS system at Soultz-sous-Forêts. Geothermics 2009;38:349-359.

Ormat, . Ormat Systems Ltd, e-mail communication from the 12/06/2010; 2010.

Baldacci, A., Brunazzi, E., Galletti, C., Paglianti, A.. Modelling and experimental validation of H2S emissions in geothermal power plants. Geothermics 2002;31:501-517.

Brown, M., Ulgiati, S.. Emergy evaluations and environmental loading of electricity production systems. Journal of Cleaner Production 2002;10:321-334.

Frondini, F., Caliro, S., Cardellini, C., Chiodini, G., Morgantini, N.. Carbon dioxide degassing and thermal energy release in the Monte Amiata volcanic-geothermal area (Italy). Applied Geochemistry 2009;24:860-875.

Intergovernmental Panel on Climate Change, . IPCC(2007) Climate Change 2007: The Scientific Basis. In: Fourth Assessment Report of the Intergovernmental Panel on Climate Change (2007). Tech. Rep.; IPCC; 2007.

Goedkoop, M., Spriensma, R.. The Eco-Indicator 99: A damage oriented method for life cycle impact assessment. Tech. Rep.; PRé Consultants; Amersfoort, The Netherlands; 2000.

OFEN, . Global energy Swiss statistics 2010. Tech. Rep.; Swiss Federal Office of Energy; Bern, Switzerland; 2010.

Maréchal, F., Kalitventzeff, B.. Targeting the minimum cost of energy requirements: A new graphical technique for evaluating the integration of utility systems. Computers \& Chemical Engineering 1996;20:S225-S230.

Dones, R., Bauer, C., Bolliger, R., Burger, B., Heck, T., Röder, A., et al. Sachbilanzen von Energiesystemen, ecoinvent report No 6. Tech. Rep.; ecoinvent center; CH-8600 Dübendorf, Switzerland; 2007. 


\section{Appendix}

\section{A Details for LCI elements}

\begin{tabular}{|c|c|c|c|c|c|}
\hline $\begin{array}{l}\text { Name of the LCI ele- } \\
\text { ment }\end{array}$ & Life cycle stage & $\begin{array}{l}\text { Conv. } \\
\text { tech. }\end{array}$ & $\begin{array}{l}\text { Functional } \\
\text { parame- } \\
\text { ters }\end{array}$ & $\begin{array}{l}\text { Reference } \\
\text { quantity } v_{k}\end{array}$ & Source \\
\hline $\begin{array}{l}\text { Diesel for site prepara- } \\
\text { tion }\end{array}$ & Site preparation & all & $s$ & $\begin{array}{l}20000 \\
\mathrm{MJ} / \text { site }\end{array}$ & $\begin{array}{l}\text { Frick } \\
\text { et al. } \\
(2010)\end{array}$ \\
\hline $\begin{array}{l}\text { Cement for site prepara- } \\
\text { tion }\end{array}$ & Site preparation & all & $s$ & $300 \mathrm{~kg} /$ site & $\begin{array}{l}\text { Frick } \\
\text { et al. } \\
(2010)\end{array}$ \\
\hline $\begin{array}{l}\text { Diesel for drilling rig } \\
\text { drive }\end{array}$ & Drilling & all & $s, z, n_{w}$ & $7.492 \mathrm{MJ} / \mathrm{m}$ & $\begin{array}{l}\text { Frick } \\
\text { et al. } \\
(2010)\end{array}$ \\
\hline Diesel for drilling mud & Drilling & all & $s, z, n_{w}$ & $181.3 \mathrm{MJ} / \mathrm{m}$ & $\begin{array}{l}\text { Frick } \\
\text { et al. } \\
(2010)\end{array}$ \\
\hline $\begin{array}{l}\text { Bentonite for drilling } \\
\text { mud }\end{array}$ & Drilling & all & $s, z, n_{w}$ & $7.7 \mathrm{~kg} / \mathrm{m}$ & $\begin{array}{l}\text { Frick } \\
\text { et al. } \\
(2010)\end{array}$ \\
\hline Starch for drilling mud & Drilling & all & $s, z, n_{w}$ & $12.8 \mathrm{~kg} / \mathrm{m}$ & $\begin{array}{l}\text { Frick } \\
\text { et al. } \\
(2010)\end{array}$ \\
\hline Chalk for drilling mud & Drilling & all & $s, z, n_{w}$ & $5.4 \mathrm{~kg} / \mathrm{m}$ & $\begin{array}{l}\text { Frick } \\
\text { et al. } \\
(2010)\end{array}$ \\
\hline Water for drilling mud & Drilling & all & $s, z, n_{w}$ & $671.4 \mathrm{~kg} / \mathrm{m}$ & $\begin{array}{l}\text { Frick } \\
\text { et al. } \\
(2010)\end{array}$ \\
\hline $\begin{array}{l}\text { Calcium carbonate for } \\
\text { drilling mud }\end{array}$ & Drilling & all & $s, z, n_{w}$ & $6.7 \mathrm{~kg} / \mathrm{m}$ & $\begin{array}{l}\text { Frick } \\
\text { et al. } \\
(2010)\end{array}$ \\
\hline Cuttings disposal & Drilling & all & $s, z, n_{w}$ & $456 \mathrm{~kg} / \mathrm{m}$ & $\begin{array}{l}\text { Frick } \\
\text { et al. } \\
(2010)\end{array}$ \\
\hline $\begin{array}{l}\text { High-alloyed steel for } \\
\text { casing }\end{array}$ & Casing & all & $s, z, n_{w}$ & $34 \mathrm{~kg} / \mathrm{m}$ & $\begin{array}{l}\text { Frick } \\
\text { et al. } \\
(2010)\end{array}$ \\
\hline $\begin{array}{l}\text { Low-alloyed steel for cas- } \\
\text { ing }\end{array}$ & Casing & all & $s, z, n_{w}$ & $69.1 \mathrm{~kg} / \mathrm{m}$ & $\begin{array}{l}\text { Frick } \\
\text { et al. } \\
(2010)\end{array}$ \\
\hline $\begin{array}{l}\text { Bentonite for cementa- } \\
\text { tion }\end{array}$ & Cementation & all & $s, z, n_{w}$ & $0.2 \mathrm{~kg} / \mathrm{m}$ & $\begin{array}{l}\text { Frick } \\
\text { et al. } \\
(2010)\end{array}$ \\
\hline $\begin{array}{l}\text { Portland cement for ce- } \\
\text { mentation }\end{array}$ & Cementation & all & $s, z, n_{w}$ & $23.5 \mathrm{~kg} / \mathrm{m}$ & $\begin{array}{l}\text { Frick } \\
\text { et al. } \\
(2010)\end{array}$ \\
\hline $\begin{array}{l}\text { Silica sand for cementa- } \\
\text { tion }\end{array}$ & Cementation & all & $s, z, n_{w}$ & $7 \mathrm{~kg} / \mathrm{m}$ & $\begin{array}{l}\text { Frick } \\
\text { et al. } \\
(2010)\end{array}$ \\
\hline $\begin{array}{l}\text { Unspecified cement for } \\
\text { cementation }\end{array}$ & Cementation & all & $s, z, n_{w}$ & $7.3 \mathrm{~kg} / \mathrm{m}$ & $\begin{array}{l}\text { Frick } \\
\text { et al. } \\
(2010)\end{array}$ \\
\hline $\begin{array}{l}\text { Water (decarbonized) } \\
\text { for cementation }\end{array}$ & Cementation & all & $s, z, n_{w}$ & $16.9 \mathrm{~kg} / \mathrm{m}$ & $\begin{array}{l}\text { Frick } \\
\text { et al. } \\
(2010)\end{array}$ \\
\hline $\begin{array}{l}\text { Diesel for reservoir en- } \\
\text { hancement }\end{array}$ & $\begin{array}{l}\text { Hydraulic stimu- } \\
\text { lations }\end{array}$ & $\begin{array}{l}\text { all } \\
37\end{array}$ & $s, n_{w}$ & 3e6 MJ/well & $\begin{array}{l}\text { Frick } \\
\text { et al. } \\
(2010)\end{array}$ \\
\hline $\begin{array}{l}\text { Water (demineralized) } \\
\text { for reservoir enhance- }\end{array}$ & $\begin{array}{l}\text { Hydraulic stimu- } \\
\text { lations }\end{array}$ & all & $s, n_{w}$ & $\begin{array}{l}269 \mathrm{e} 6 \\
\mathrm{MJ} / \text { well }\end{array}$ & $\begin{array}{l}\text { Frick } \\
\text { et al. }\end{array}$ \\
\hline
\end{tabular}




\begin{tabular}{|c|c|c|c|c|c|c|}
\hline $\begin{array}{l}\text { Name of the LCI } \\
\text { element }\end{array}$ & $\begin{array}{l}\text { Life } \\
\text { stage }\end{array}$ & cycle & $\begin{array}{l}\text { Conv. } \\
\text { tech. }\end{array}$ & $\begin{array}{l}\text { Functional } \\
\text { parame- } \\
\text { ters }\end{array}$ & $\begin{array}{l}\text { Reference } \\
\text { quantity } v_{k}\end{array}$ & Source \\
\hline $\begin{array}{l}\text { Water make-up for } \\
\text { EGS }\end{array}$ & $\begin{array}{l}\text { EGS } \\
\text { tion }\end{array}$ & opera- & all & $l_{\text {wat }}, \dot{m}_{f}$ & from model & $\begin{array}{l}\text { Gerber } \\
\text { and } \\
\text { Maréchal } \\
(2012)\end{array}$ \\
\hline $\begin{array}{l}\text { Transport by lorry } \\
\text { for scaling and } \\
\text { residues }\end{array}$ & $\begin{array}{l}\text { EGS } \\
\text { tion }\end{array}$ & opera- & all & - & $250 \mathrm{tkm} / \mathrm{yr}$ & $\begin{array}{l}\text { Frick } \\
\text { et al. } \\
(2010)\end{array}$ \\
\hline $\begin{array}{l}\text { Disposal of scaling } \\
\text { and residues }\end{array}$ & $\begin{array}{l}\text { EGS } \\
\text { tion }\end{array}$ & opera- & all & $\dot{m}_{e x t}$ & $\begin{array}{l}1.5 \\
\mathrm{~kg} / \mathrm{yr} \cdot \mathrm{m}^{3} / \mathrm{h}\end{array}$ & $\begin{array}{l}\text { Frick } \\
\text { et al. } \\
(2010)\end{array}$ \\
\hline $\begin{array}{l}\text { Equipment mainte- } \\
\text { nance }\end{array}$ & $\begin{array}{l}\text { EGS } \\
\text { tion }\end{array}$ & opera- & all & $I_{p e}$ & from model & $\begin{array}{l}\text { Gerber } \\
\text { et al. } \\
(2011)\end{array}$ \\
\hline $\begin{array}{l}\text { Fossil CO2 emitted } \\
\text { at condenser }\end{array}$ & $\begin{array}{l}\text { EGS } \\
\text { tion }\end{array}$ & opera- & $\begin{array}{l}\text { 1- and 2- } \\
\text { flash }\end{array}$ & $\dot{m}_{f}, e_{C_{2}}$ & from model & $\begin{array}{l}\text { Baldacci } \\
\text { et al. } \\
(2002)\end{array}$ \\
\hline $\begin{array}{l}\text { H2S emitted at con- } \\
\text { denser }\end{array}$ & $\begin{array}{l}\text { EGS } \\
\text { tion }\end{array}$ & opera- & $\begin{array}{l}\text { 1- and 2- } \\
\text { flash }\end{array}$ & $\dot{m}_{f}, e_{H_{2} S}$ & from model & $\begin{array}{l}\text { Baldacci } \\
\text { et al. } \\
(2002)\end{array}$ \\
\hline $\begin{array}{l}\text { Fossil CH4 emitted } \\
\text { at condenser }\end{array}$ & $\begin{array}{l}\text { EGS } \\
\text { tion }\end{array}$ & opera- & $\begin{array}{l}\text { 1- and 2- } \\
\text { flash }\end{array}$ & $\dot{m}_{f}, e_{C H_{4}}$ & from model & $\begin{array}{l}\text { Baldacci } \\
\text { et al. } \\
(2002)\end{array}$ \\
\hline $\begin{array}{l}\text { H2 emitted at con- } \\
\text { denser }\end{array}$ & $\begin{array}{l}\text { EGS } \\
\text { tion }\end{array}$ & opera- & $\begin{array}{l}\text { 1- and 2- } \\
\text { flash }\end{array}$ & $\dot{m}_{f}, e_{H_{2}}$ & from model & $\begin{array}{l}\text { Baldacci } \\
\text { et al. } \\
(2002)\end{array}$ \\
\hline $\begin{array}{l}\text { NH3 emitted at con- } \\
\text { denser }\end{array}$ & $\begin{array}{l}\text { EGS } \\
\text { tion }\end{array}$ & opera- & $\begin{array}{l}\text { 1- and 2- } \\
\text { flash }\end{array}$ & $\dot{m}_{f}, e_{N H_{3}}$ & from model & $\begin{array}{l}\text { Baldacci } \\
\text { et al. } \\
(2002)\end{array}$ \\
\hline $\begin{array}{l}\text { Working fluid loss for } \\
\text { binary cycles }\end{array}$ & $\begin{array}{l}\text { EGS } \\
\text { tion }\end{array}$ & opera- & $\begin{array}{l}\text { ORCs, } \\
\text { Kalina }\end{array}$ & $l_{w f}, w f, \dot{E}_{t, p}^{-}$ & from model & $\begin{array}{l}\text { Ormat } \\
(2010)\end{array}$ \\
\hline $\begin{array}{l}\text { Working fluid make- } \\
\text { up for binary cycles }\end{array}$ & $\begin{array}{l}\text { EGS } \\
\text { tion }\end{array}$ & opera- & $\begin{array}{l}\text { ORCs, } \\
\text { Kalina }\end{array}$ & $l_{w f}, w f, \dot{E}_{t, p}^{-}$ & from model & $\begin{array}{l}\text { Ormat } \\
(2010)\end{array}$ \\
\hline $\begin{array}{l}\text { Transport for work- } \\
\text { ing fluid make-up }\end{array}$ & $\begin{array}{l}\text { EGS } \\
\text { tion }\end{array}$ & opera- & $\begin{array}{l}\text { ORCs, } \\
\text { Kalina }\end{array}$ & $l_{w f}, w f, \dot{E}_{t, p}^{-}, d$ & from model & $\begin{array}{l}\text { distance } \\
\text { as- } \\
\text { sumed }\end{array}$ \\
\hline $\begin{array}{l}\text { Avoided electricity } \\
\text { from NGCC }\end{array}$ & $\begin{array}{l}\text { EGS } \\
\text { tion }\end{array}$ & opera- & all & $\dot{E}_{p}^{-}\left(z, x_{d}\right), \dot{Q}_{p}^{-}$ & from model & $\begin{array}{l}\text { Gerber } \\
\text { and } \\
\text { Maréchal } \\
(2012)\end{array}$ \\
\hline $\begin{array}{l}\text { Avoided district } \\
\text { heating from natural } \\
\text { gas condensing boiler }\end{array}$ & $\begin{array}{l}\text { EGS } \\
\text { tion }\end{array}$ & opera- & all & $\dot{E}_{p}^{-}\left(z, x_{d}\right), \dot{Q}_{p}^{-}$ & from model & $\begin{array}{l}\text { Gerber } \\
\text { and } \\
\text { Maréchal } \\
(2012)\end{array}$ \\
\hline
\end{tabular}

Table 4: Summary of the different LCI elements included in the LCA model for operation, and of the parameters used for their scaling and adaptation to the configuration 


\begin{tabular}{|c|c|c|c|c|c|}
\hline $\begin{array}{l}\text { Name of the LCI } \\
\text { element }\end{array}$ & $\begin{array}{l}\text { Life cycle } \\
\text { stage }\end{array}$ & $\begin{array}{l}\text { Conv. } \\
\text { tech. }\end{array}$ & $\begin{array}{l}\text { Functional } \\
\text { parame- } \\
\text { ters }\end{array}$ & $\begin{array}{l}\text { Reference } \\
\text { quantity } v_{k}\end{array}$ & Source \\
\hline $\begin{array}{l}\text { Gravel for well dis- } \\
\text { mantling }\end{array}$ & Dismantling & all & $s, z, n_{w}$ & $51.1 \mathrm{~kg} / \mathrm{m}$ & $\begin{array}{l}\text { Frick } \\
\text { et al. } \\
(2010)\end{array}$ \\
\hline $\begin{array}{l}\text { Cement for well dis- } \\
\text { mantling }\end{array}$ & Dismantling & all & $s, z, n_{w}$ & $4.9 \mathrm{~kg} / \mathrm{m}$ & $\begin{array}{l}\text { Frick } \\
\text { et al. } \\
(2010)\end{array}$ \\
\hline Equipment disposal & Dismantling & all & $r$ & from model & $\begin{array}{l}\text { Gerber } \\
\text { et al. } \\
(2011)\end{array}$ \\
\hline $\begin{array}{l}\text { Working fluid loss at } \\
\text { dismantling }\end{array}$ & Dismantling & all & $l_{w f, e o l}$ & from model & $\begin{array}{l}\text { Saner } \\
\text { et al. } \\
(2010)\end{array}$ \\
\hline
\end{tabular}

Table 5: Summary of the different LCI elements included in the LCA model for end-of-life, and of the parameters used for their scaling and adaptation to the configuration 


\begin{tabular}{|c|c|c|c|}
\hline Abbreviation & Description & Unit & Quantity (if fixed) \\
\hline$s$ & Percentage of success in EGS construction & - & 1 \\
\hline$z$ & Construction depth of EGS & $\mathrm{m}$ & $3000-10000$ \\
\hline$n_{w}$ & Number of wells & - & 3 \\
\hline$\dot{E}_{g e o}^{+}$ & $\begin{array}{l}\text { Electricity consumed by the geothermal } \\
\text { pumps }\end{array}$ & $\mathrm{kW}$ & from model \\
\hline$\dot{m}_{i n j}$ & Injected water mass flow rate in EGS & $\mathrm{kg} / \mathrm{s}$ & 100 \\
\hline$d P_{i n j}$ & Pressure drop inside EGS & bar & 100 \\
\hline$P_{i n j}$ & Pressure at which water is injected ${ }^{\mathrm{a}}$ & bar & from model \\
\hline$m_{f}$ & $\begin{array}{l}\text { steam mass flow rate passing through the } \\
\text { flash turbines }\end{array}$ & $\mathrm{kg} / \mathrm{s}$ & from model \\
\hline$T_{\text {ext }}$ & Temperature at extraction well & ${ }^{\circ} \mathrm{C}$ & from model \\
\hline$d P_{f}$ & Pressure drop inside flash drums & bar & from model \\
\hline$\dot{Q}^{-}$ & District heating requirements & $\mathrm{kW}$ & $0-60000$ \\
\hline$\dot{E}_{t}^{-}$ & Electricity produced at turbine & $\mathrm{kW}$ & from model \\
\hline$\dot{E}^{-}$ & $\begin{array}{l}\text { Net electricity produced by the conversion } \\
\text { system }^{\text {b }}\end{array}$ & $\mathrm{kW}$ & from model \\
\hline$T_{a}$ & Temperature of the ambiance & ${ }^{\circ} \mathrm{C}$ & 10 \\
\hline$w f$ & Choice of working fluid & - & see Table 1 \\
\hline$l_{\text {wat }}$ & Percentage of water losses inside EGS & - & 0.1 \\
\hline$\dot{m}_{\text {ext }}$ & Water mass flow rate at extraction well & $\mathrm{kg} / \mathrm{s}$ & 90 \\
\hline$I_{p e}$ & $\begin{array}{l}\text { Yearly percentage of initial impact for pro- } \\
\text { cess equipment }\end{array}$ & - & 0.05 Gerber et al. (2011) \\
\hline$e_{\mathrm{CO}_{2}}$ & $\begin{array}{l}\text { Specific CO2 emissions per unit of flashed } \\
\text { geothermal steam }\end{array}$ & $\mathrm{kg}-\mathrm{CO} 2 / \mathrm{kg}$-steam & 0.0366 Baldacci et al. (2002) \\
\hline$e_{H_{2} S}$ & $\begin{array}{l}\text { Specific H2S emissions per unit of flashed } \\
\text { geothermal steam }\end{array}$ & $\mathrm{kg}-\mathrm{H} 2 \mathrm{~S} / \mathrm{kg}$-steam & 4.85 e-4 Baldacci et al. (2002) \\
\hline$e_{\mathrm{CH}_{4}}$ & $\begin{array}{l}\text { Specific CH4 emissions per unit of flashed } \\
\text { geothermal steam }\end{array}$ & $\mathrm{kg}-\mathrm{CH} 4 / \mathrm{kg}$-steam & 2.6 e-4 Baldacci et al. (2002) \\
\hline$e_{H_{2}}$ & $\begin{array}{l}\text { Specific H2 emissions per unit of flashed } \\
\text { geothermal steam }\end{array}$ & kg-H2/kg-steam & 2.75 e-5 Baldacci et al. (2002) \\
\hline$e_{N H_{3}}$ & $\begin{array}{l}\text { Specific NH3 emissions per unit of flashed } \\
\text { geothermal steam }\end{array}$ & $\mathrm{kg}-\mathrm{NH} 3 / \mathrm{kg}$-steam & 1.175 e-4 Baldacci et al. (2002) \\
\hline$l_{w f}$ & $\begin{array}{l}\text { Yearly percentage of initial amount of } \\
\text { working fluid lost in the atmosphere }\end{array}$ & - & 0.02 Ormat $(2010)$ \\
\hline$d$ & Transport distance for working fluid & $\mathrm{km}$ & 50 \\
\hline$l_{w f, e o l}$ & $\begin{array}{l}\text { Percentage of working fluid lost during } \\
\text { plant dismantling }\end{array}$ & - & 0.2 Saner et al. (2010) \\
\hline$r$ & $\begin{array}{l}\text { Recycling ratio for each type of process } \\
\text { equipment }\end{array}$ & - & 0.5-0.98 Gerber et al. (2011) \\
\hline
\end{tabular}

Table 6: Description of the parameters used to express the LCI elements

${ }^{\text {a }}$ calculated to keep water in liquid state at the temperature corresponding to depth $z$ after pressure drop

${ }^{\mathrm{b}}$ after removal of parasitic losses (geothermal pumps, cycle pumps) 
B Supplementary results for final optimal configurations

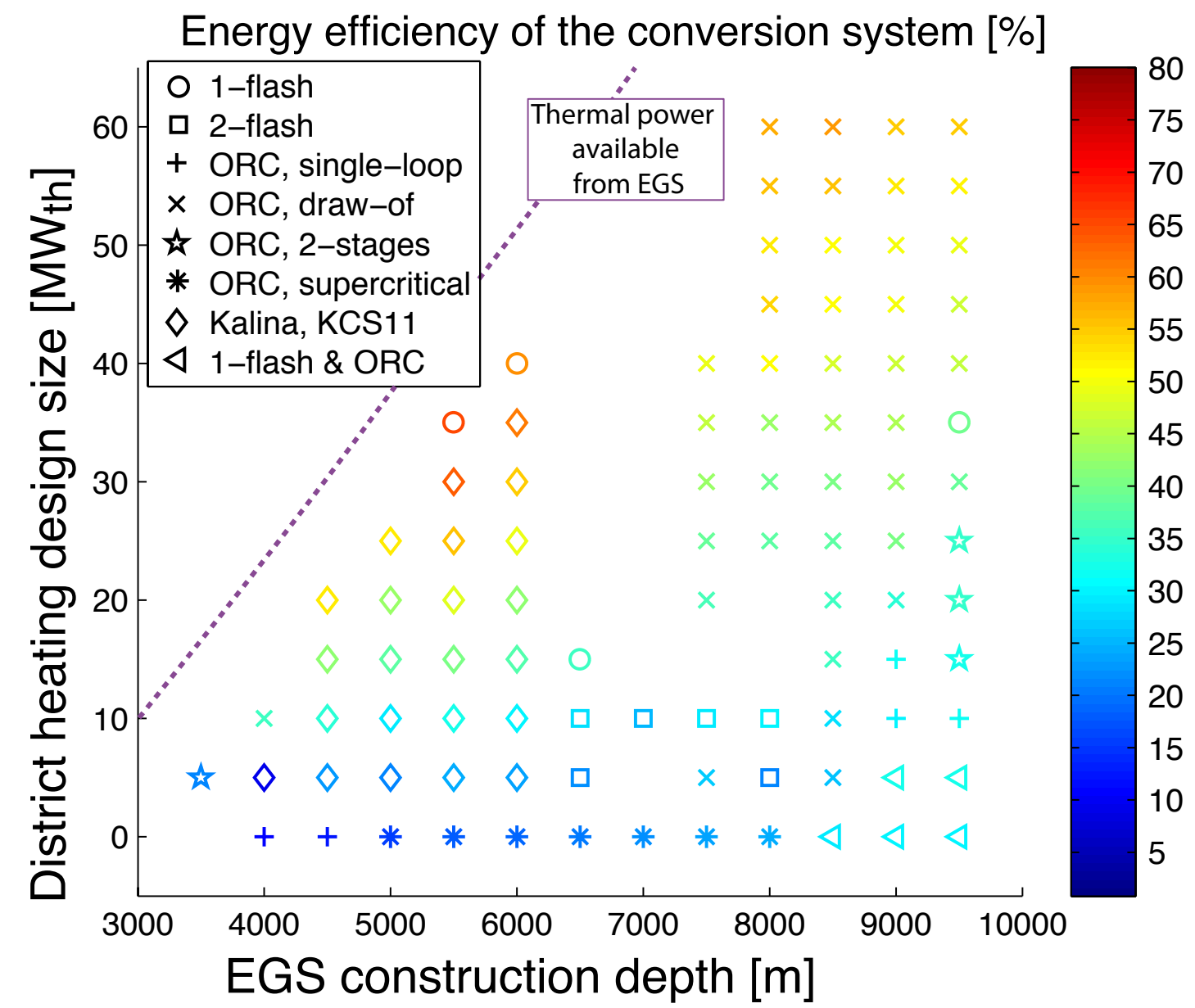

Figure 13: Yearly energy efficiencies (including electricity and district heating) associated with the best configurations of Figure 5 


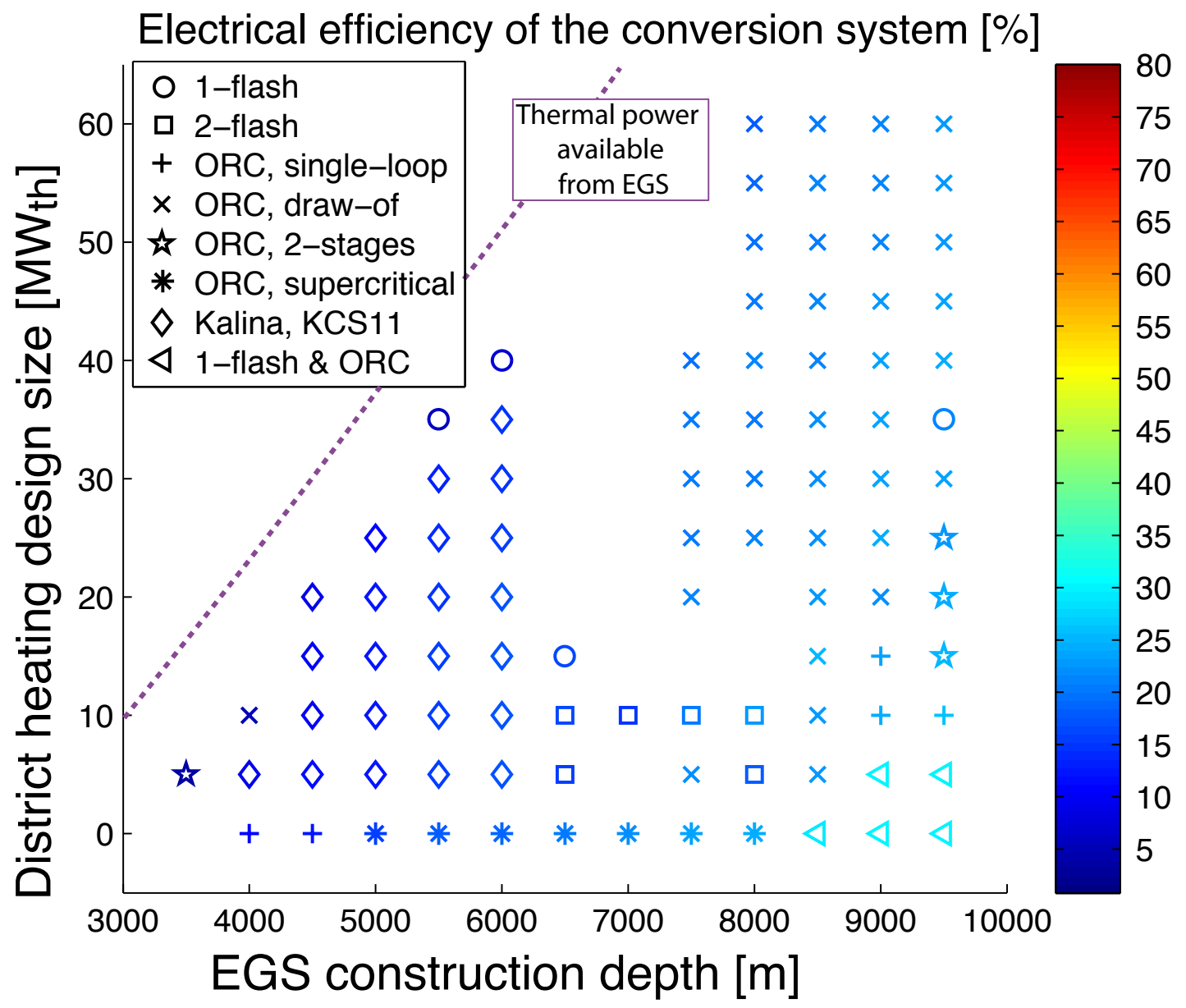

Figure 14: Yearly electrical efficiencies (electricity production only) associated with the best configurations of Figure 5 


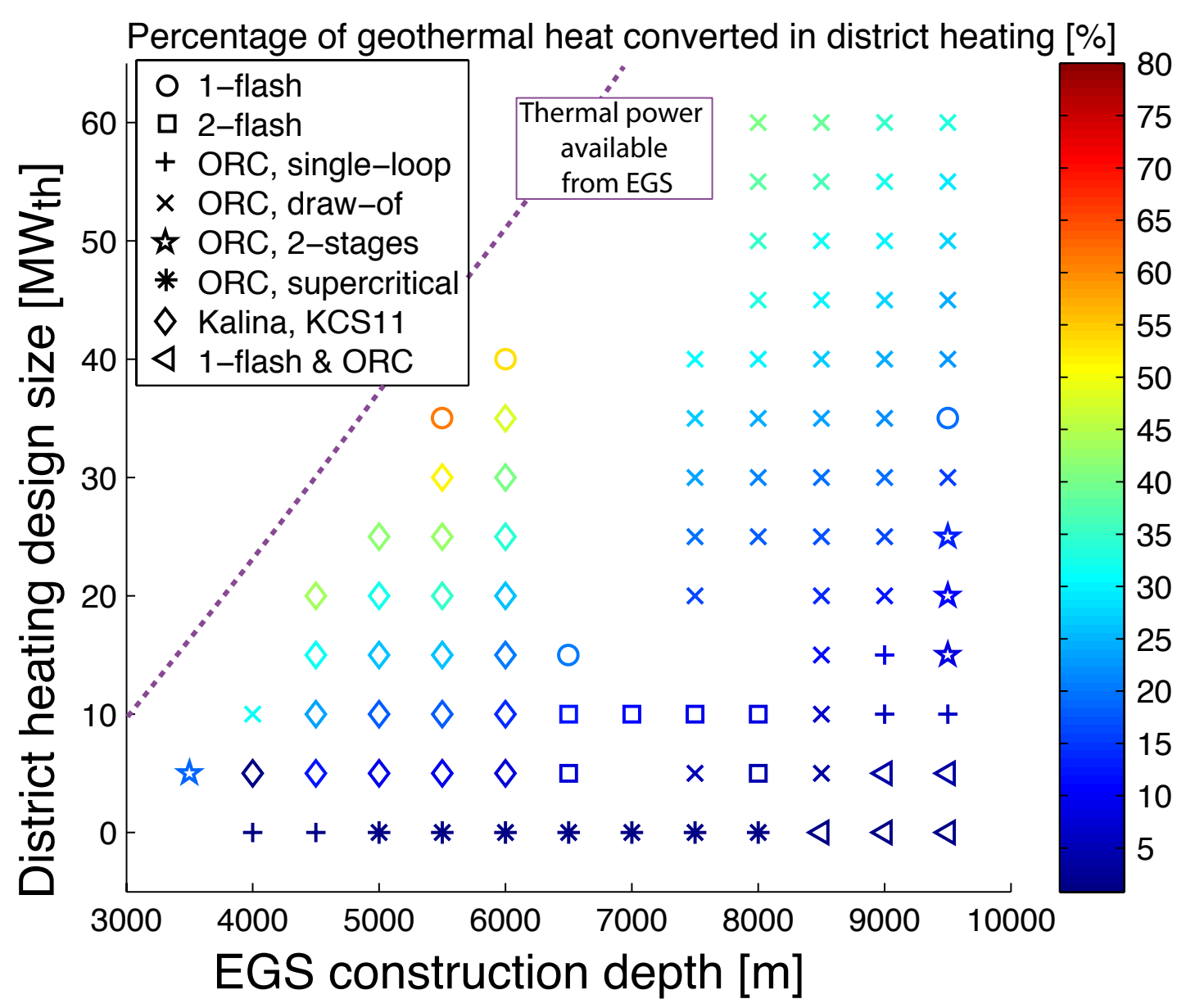

Figure 15: Yearly efficiencies for the conversion of geothermal heat in district heating associated with the best configurations of Figure 5

\begin{tabular}{|l|c|}
\hline Temperature at extraction well, in ${ }^{\circ} \mathrm{C}$ & 219 \\
Temperature at reinjection well, in ${ }^{\circ} \mathrm{C}$ & 80 \\
Thermal power available from EGS, in $\mathrm{MW}_{t h}$ & 54.0 \\
Exergy available from EGS, in MW & 17.5 \\
\hline Higher pressure of supercritical ORC, in bar & 55 \\
Superheating temperature of supercritical ORC, in ${ }^{\circ} \mathrm{C}$ & 209 \\
\hline Electrical power produced by cycle, in $\mathrm{MW}_{e}$ & 12.0 \\
Parasitic losses, in MW $e$ & 1.1 \\
Net electrical power produced, in $\mathrm{MW}_{e}$ & 10.9 \\
\hline Energy/Electrical efficiency, in $\%$ & 20.2 \\
Exergy efficiency, in $\%$ & 62.3 \\
\hline
\end{tabular}

Table 7: Operating conditions of the configuration using a supercritical ORC with R134a for single electricity production at $6500 \mathrm{~m}$ (configuration 1 on Figure 5) 


\begin{tabular}{|l|c|c|c|c|}
\hline & Interseason & Winter & Summer & Design \\
\hline Operating time, in h & 3942 & 4205 & 525 & 88 \\
\hline $\begin{array}{l}\text { Temperature at extrac- } \\
\text { tion well, in }{ }^{\circ} \mathrm{C}\end{array}$ & 201 & 201 & 201 & 201 \\
$\begin{array}{l}\text { Temperature at reinjec- } \\
\text { tion well, in }{ }^{\circ} \mathrm{C}\end{array}$ & 106 & 106 & 106 & 106 \\
$\begin{array}{l}\text { Thermal power available } \\
\text { from EGS, in MW }\end{array}$ & 37.2 & 37.2 & 37.2 & 37.2 \\
$\begin{array}{l}\text { Exergy available from } \\
\text { EGS, in MW }\end{array}$ & 12.4 & 12.4 & 12.4 & 12.4 \\
\hline $\begin{array}{l}\text { Higher pressure of } \\
\text { Kalina cycle, in bar }\end{array}$ & 36 & 36 & 36 & 36 \\
$\begin{array}{l}\text { Lower pressure of Kalina } \\
\text { cycle, in bar }\end{array}$ & 6 & 7.5 & 6 & 6 \\
$\begin{array}{l}\text { Ammonia concentration } \\
\text { in working fluid of }\end{array}$ & 0.805 & 0.805 & 0.805 & 0.805 \\
Kalina cycle & 1.1 & 1.1 & 1.1 & 1.1 \\
\hline $\begin{array}{l}\text { District heating demand, } \\
\text { in MW }\end{array}$ & 9.2 & 21.3 & 4.8 & 30 \\
$\begin{array}{l}\text { Electrical power pro- } \\
\text { duced by cycle, in } \\
\text { MW }{ }_{e}\end{array}$ & 7.2 & 5.8 & 7.2 & 2.2 \\
$\begin{array}{l}\text { Parasitic losses, in MW } \\
\text { Net electrical power pro- } \\
\text { duced, in MW }\end{array}$ & 6.1 & 70.0 & 29.4 & 83.8 \\
\hline $\begin{array}{l}\text { Energy efficiency, in \% } \\
\text { Electrical efficiency, in \% } \\
\text { Exergy efficiency, in \% }\end{array}$ & 54.8 & 54.1 & 51.9 & 38.1 \\
\hline
\end{tabular}

Table 8: Operating conditions of the configuration using a Kalina cycle with a district heating design size of $30 \mathrm{MW}$ at $6000 \mathrm{~m}$ (configuration 2 on Figure 5) 


\begin{tabular}{|l|c|c|c|c|}
\hline & Interseason & Winter & Summer & Design \\
\hline Operating time, in h & 3942 & 4205 & 525 & 88 \\
\hline $\begin{array}{l}\text { Temperature at extrac- } \\
\text { tion well, in }{ }^{\circ} \mathrm{C}\end{array}$ & 272 & 272 & 272 & 272 \\
$\begin{array}{l}\text { Temperature at reinjec- } \\
\text { tion well, in }{ }^{\circ} \mathrm{C}\end{array}$ & 116 & 102 & 129 & 85 \\
$\begin{array}{l}\text { Thermal power available } \\
\text { from EGS, in MW }\end{array}$ & 63.3 & 68.3 & 58.1 & 74.9 \\
$\begin{array}{l}\text { Exergy available from } \\
\text { EGS, in MW }\end{array}$ & 24.5 & 25.8 & 23.1 & 27.2 \\
\hline $\begin{array}{l}\text { Flashing temperature of } \\
\text { 1st flash drum, in }{ }^{\circ} \mathrm{C}\end{array}$ & 215 & 217 & 258 & 268 \\
$\begin{array}{l}\text { Flashing temperature of } \\
\text { 2nd flash drum, in }{ }^{\circ} \mathrm{C}\end{array}$ & 165 & 169 & 256 & 256 \\
\hline $\begin{array}{l}\text { District heating demand, } \\
\text { in MW } \\
\text { th }\end{array}$ & 3.1 & 7.1 & 1.6 & 10 \\
$\begin{array}{l}\text { Electrical power pro- } \\
\text { duced by cycle, in } \\
\text { MW } \\
\text { Parasitic losses, in MW }\end{array}$ & 16.6 & 16.3 & 3.8 & 3.8 \\
$\begin{array}{l}\text { Net electrical power pro- } \\
\text { duced, in MW }\end{array}$ & 15.5 & 15.2 & 2.7 & 2.7 \\
\hline $\begin{array}{l}\text { Energy efficiency, in \% } \\
\text { Electrical efficiency, in \% } \\
\text { Exergy efficiency, in \% }\end{array}$ & 29.4 & 32.7 & 7.4 & 17.0 \\
\hline
\end{tabular}

Table 9: Operating conditions of the configuration using a 2-flash system with a district heating design size of $10 \mathrm{MW}$ at $8000 \mathrm{~m}$ (configuration 3 on Figure 5)

\begin{tabular}{|l|c|}
\hline Temperature at extraction well, in ${ }^{\circ} \mathrm{C}$ & 324 \\
Temperature at reinjection well, in ${ }^{\circ} \mathrm{C}$ & 84 \\
Thermal power available from EGS, in $\mathrm{MW}_{t h}$ & 101.5 \\
Exergy available from EGS, in MW & 40.0 \\
\hline Flashing temperature of 1 st flash drum, in ${ }^{\circ} \mathrm{C}$ & 313 \\
Evaporation temperature of ORC, in ${ }^{\circ} \mathrm{C}$ & 114 \\
Superheating temperature of ORC, in ${ }^{\circ} \mathrm{C}$ & 294 \\
\hline Electrical power produced by flash, in $\mathrm{MW}_{e}$ & 4.0 \\
Electrical power produced by ORC, in $\mathrm{MW}_{e}$ & 26.6 \\
Parasitic losses, in MW $e$ & 1.1 \\
Net electrical power produced, in $\mathrm{MW}$ & 29.5 \\
\hline Energy/Electrical efficiency, in $\%$ & 29.1 \\
Exergy efficiency, in $\%$ & 73.7 \\
\hline
\end{tabular}

Table 10: Operating conditions of the configuration using a 1-flash and a bottoming ORC with iso-butane for single electricity production at $9500 \mathrm{~m}$ (configuration 4 on Figure 5) 


\begin{tabular}{|c|c|c|c|c|}
\hline & Interseason & Winter & Summer & Design \\
\hline Operating time, in $\mathrm{h}$ & 3942 & 4205 & 525 & 88 \\
\hline $\begin{array}{l}\text { Temperature at extrac- } \\
\text { tion well, in }{ }^{\circ} \mathrm{C}\end{array}$ & 324 & 324 & 324 & 324 \\
\hline $\begin{array}{l}\text { Temperature at reinjec- } \\
\text { tion well, in }{ }^{\circ} \mathrm{C}\end{array}$ & 114 & 100 & 130 & 101 \\
\hline $\begin{array}{l}\text { Thermal power available } \\
\text { from EGS, in } \mathrm{MW}_{t h}\end{array}$ & 90.0 & 95.3 & 83.9 & 94.7 \\
\hline $\begin{array}{l}\text { Exergy available from } \\
\text { EGS, in MW }\end{array}$ & 37.4 & 38.7 & 35.6 & 38.6 \\
\hline $\begin{array}{l}\text { Evaporation } \frac{2}{\text { temper- }} \\
\text { ature of ORC, in } \\
{ }^{\circ} \mathrm{C}\end{array}$ & 125 & 127 & 125 & 109 \\
\hline $\begin{array}{l}\text { Superheating tem- } \\
\text { perature of ORC, in } \\
{ }^{\circ} \mathrm{C}\end{array}$ & 308 & 311 & 313 & 309 \\
\hline $\begin{array}{l}\text { Condensation temper- } \\
\text { ature of intermediate } \\
\text { draw-off in } \mathrm{ORC} \text {, in }{ }^{\circ} \mathrm{C}\end{array}$ & 41 & 49 & 40 & 56 \\
\hline $\begin{array}{l}\text { Splitting fraction for in- } \\
\text { termediate draw-off of } \\
\text { ORC, in } \%\end{array}$ & 32 & 51 & 60 & 48 \\
\hline $\begin{array}{l}\text { District heating demand, } \\
\text { in } \mathrm{MW}_{t h}\end{array}$ & 18.4 & 42.6 & 9.7 & 60 \\
\hline $\begin{array}{l}\text { Electrical power pro- } \\
\text { duced by cycle, in } \\
\mathrm{MW}_{e}\end{array}$ & 23.3 & 20.7 & 20.5 & 11.9 \\
\hline Parasitic losses, in $\mathrm{MW}_{e}$ & 1.1 & 1.1 & 1.1 & 1.1 \\
\hline $\begin{array}{l}\text { Net electrical power pro- } \\
\text { duced, in } \mathrm{MW}_{e}\end{array}$ & 22.2 & 19.6 & 19.4 & 10.8 \\
\hline Energy efficiency, in \% & 45.1 & 65.2 & 34.7 & 74.8 \\
\hline Electrical efficiency, in \% & 24.7 & 20.6 & 23.2 & 11.4 \\
\hline Exergy efficiency, in \% & 62.6 & 61.0 & 56.1 & 46.8 \\
\hline
\end{tabular}

Table 11: Operating conditions of the configuration using an ORC with an intermediate draw-off using cyclo-butane, with a district heating design size of $60 \mathrm{MW}$ at $9500 \mathrm{~m}$ (configuration 5 on Figure 5) 


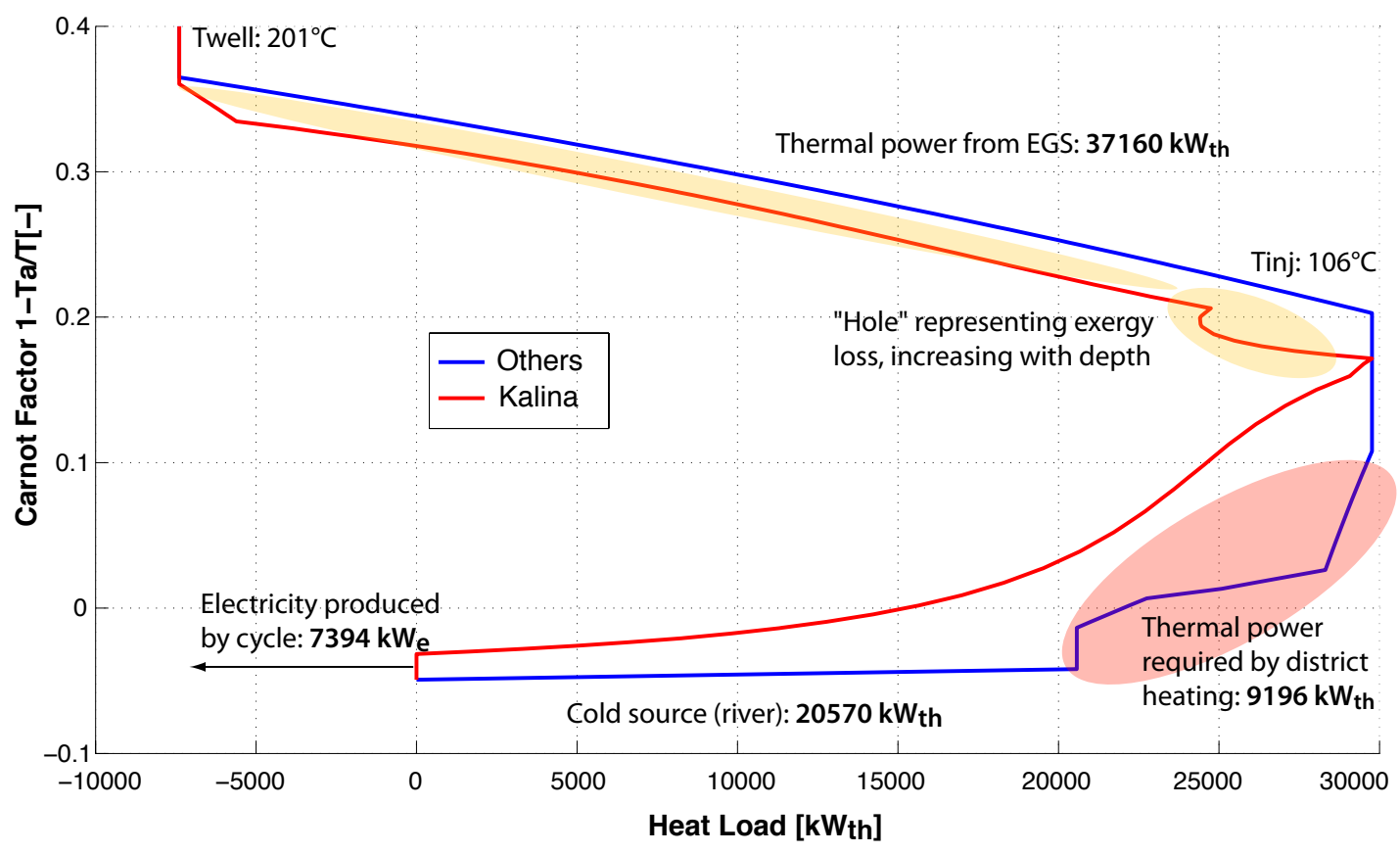

Figure 16: Integrated exergy composite curve of a Kalina cycle with a 6000m EGS and a district heating installed capacity of $30 \mathrm{MW}_{t h}$ operating during interseason 